ISSN 1999-4915

www.mdpi.com/journal/viruses

Review

\title{
Drug Resistance in Non-B Subtype HIV-1: Impact of HIV-1 Reverse Transcriptase Inhibitors
}

Kamalendra Singh ${ }^{1,2, \dagger}$, Jacqueline A. Flores ${ }^{1,2, \dagger}$, Karen A. Kirby ${ }^{1,2}$, Ujjwal Neogi ${ }^{3}$, Anders Sonnerborg ${ }^{3}$, Atsuko Hachiya ${ }^{4}$, Kalyan Das ${ }^{5,6}$, Eddy Arnold 5,6, Carole McArthur ${ }^{7}$, Michael Parniak ${ }^{8}$ and Stefan G. Sarafianos $1,2,9, *$

1 Christopher Bond Life Sciences Center, University of Missouri, Columbia, MO 65211, USA; singhka@missouri.edu (K.S.); jaf468@mail.missouri.edu (J.A.F); kirbyk@missouri.edu (K.A.K.) Department of Molecular Microbiology and Immunology, University of Missouri, Columbia, MO 65211, USA

3 Division of Clinical Microbiology, Department of Laboratory Medicine, Karolinska Institute, Stockholm 141 86, Sweden; E-Mails: ujjwal.neogi@ki.se; (U.N.); Anders.Sonnerborg@ki.se (A.S.)

4 Clinical Research Center, Department of Infectious Diseases and Immunology, National Hospital Organization, Nagoya Medical Center, Nagoya 460-0001, Japan; E-Mail: hachiya@mail-nmc.jp

5 Center for Advanced Biotechnology and Medicine, Rutgers University, Piscataway, NJ 08854, USA, E-Mails: kalyan@cabm.rutgers.edu (K.D.); arnold@cabm.rutgers.edu (E.A.)

6 Department of Chemistry and Chemical Biology, Rutgers University, Piscataway, NJ 08854, USA

7 Department of Oral and Craniofacial Science, School of Dentistry, University of Missouri, Kansas City, MO 64108, USA; E-Mail: McArthurC@umkc.edu

8 Department of Microbiology and Molecular Genetics, University of Pittsburgh School of Medicine, Pittsburgh, PA 15219, USA; E-Mail: map167@pitt.edu

9 Department of Biochemistry, University of Missouri, Columbia, MO 65211, USA

$\dagger$ These authors contributed equally to this work.

* Author to whom correspondence should be addressed; E-Mail: sarafianoss@missouri.edu; Tel.: +1-573-882-4338.

Received: 16 July 2014; in revised form: 9 September 2014 / Accepted: 9 September 2014 / Published: 24 September 2014

Abstract: Human immunodeficiency virus (HIV) causes approximately 2.5 million new infections every year, and nearly 1.6 million patients succumb to HIV each year. Several factors, including cross-species transmission and error-prone replication have resulted in extraordinary genetic diversity of HIV groups. One of these groups, known as group M 
(main) contains nine subtypes (A-D, F-H and J-K) and causes $\sim 95 \%$ of all HIV infections. Most reported data on susceptibility and resistance to anti-HIV therapies are from subtype B HIV infections, which are prevalent in developed countries but account for only $\sim 12 \%$ of all global HIV infections, whereas non-B subtype HIV infections that account for $\sim 88 \%$ of all HIV infections are prevalent primarily in low and middle-income countries. Although the treatments for subtype B infections are generally effective against non-B subtype infections, there are differences in response to therapies. Here, we review how polymorphisms, transmission efficiency of drug-resistant strains, and differences in genetic barrier for drug resistance can differentially alter the response to reverse transcriptase-targeting therapies in various subtypes.

Keywords: HIV-1 reverse transcriptase; HIV subtypes; nucleoside RT inhibitors; non-nucleoside RT inhibitors; translocation defective RT inhibitors; drug resistance

\section{Introduction}

Approximately 35 million people are infected with different types and subtypes of HIV. Of the two major HIV types, HIV type 1 (HIV-1) causes $\sim 95 \%$ of all infections, whereas HIV-2 ( 5\%) is mainly limited to West African countries (Senegal, Mali, Ghana, Guinea-Bissau, the Gambia, Niger, Cote d'Ivoire, and Liberia). HIV-1 has been divided into four groups: major (M), outlier (O), non-M/non-O $(\mathrm{N})$, and a new group P [1,2]. Group M accounts for more than 95\% of all reported HIV-1 infections [3].

Group $\mathrm{M}$ has been further divided into nine subtypes (also called clades): A-D, F-H, and J-K [2]. Of these, subtype $\mathrm{C}$ (HIV-1C) is the most prevalent worldwide and accounts for $50 \%-55 \%$ of all HIV infections [4]. It is mainly found in sub-Saharan Africa, Brazil, and India [4]. Subtype A (HIV-1A), which is approximately $20 \%$ of all HIV-1 infections, is primarily found in Eastern Europe, Northern Asia, and Western-Africa [4]. HIV-1 subtype B (HIV-1B) accounts for $\sim 12 \%$ worldwide HIV-1 infections and is the main strain reported in developed countries (North America, Western Europe, Japan, and Australia). Other HIV-1 subtypes (D-K, or HIV-1D, HIV-1K, etc.) are rare (less than $6 \%$ of all infections). In addition to nine group M (HIV-M) subtypes, 66 circulating recombinant forms (CRFs) that evolve by recombination of two or more subtypes have been reported [5]. Although generally the geographic distribution of CRFs is not well defined, the CRF01_AE and CRF02_AG CRFs are predominately found in Southeast Asia and West Africa, respectively [6,7].

Most available drug-resistance data are derived from studies on HIV-1B, mainly because of the early availability of drugs and drug-resistance testing in developed countries. In contrast, similar data on nonB subtypes of HIV-1 (HIV-non-B) are limited, primarily due to historic delays in the availability of antiretroviral therapies (ART) in resource-limited countries. Increased access to ARTs, however, with significantly high non-adherence together with factors such as high rate of mutation, viral transmission and recombination in HIV-non-B infected patients have resulted in the emergence of drug-resistance data for other subtypes [8].

High genetic diversity of HIV-1 subtypes may influence the resistance pathways to currently used antiretrovirals (ARVs) [7]. The genetic differences can also impact the extent of cross-resistance 
to ARVs of the same class and lead to virologic failure, which may affect clinical outcome and immunological response [7,9]. Moreover, there is a considerable body of evidence that shows naturally occurring polymorphisms affect ARV response in subtype B virus [10-17]. A similar effect of polymorphisms can also be hypothesized for HIV-non-B viruses. In fact, recent reports have suggested that naturally occurring polymorphisms in HIV-non-B affect susceptibility to ARVs [18], although the impact of these polymorphisms on drug resistance is not well understood.

Current anti-HIV therapies, also known as highly active antiretroviral therapies (HAART), typically comprise combinations of nucleoside/nucleotide reverse transcriptase inhibitors (NRTIs), non-nucleoside reverse transcriptase inhibitors (NNRTIs), protease inhibitors (PIs), and integrase inhibitors (INSTIs). Generally, these ARVs are also effective against HIV-non-B viruses, even though they were originally designed and developed targeting HIV-1B virus. Nonetheless, susceptibility to ARVs can vary dramatically depending upon subtype due to inherent polymorphisms and cross-species transmission routes that may create differences in the drug resistance mechanisms of HIV-1 subtypes. Here, we summarize the status of HIV-non-B resistance to currently used ARTs in low- and middle-income countries, and present a comprehensive comparison with HIV-1B.

\section{Resistance to Antiretroviral Therapies among Different HIV-1 Subtypes}

Six different classes of drugs have been approved by US Food and Drug Administration (FDA) [19] for HIV-1 treatment. The two drug classes: (i) NRTIs; and (ii) NNRTIs target the viral enzyme reverse transcriptase (RT). RT is a multi-functional enzyme. It carries out both RNA- and DNA-dependent DNA polymerase activities, as well as RNase $\mathrm{H}$ activity (Figure 1). All three activities are required for the synthesis of dsDNA from viral ssRNA genome. Structures of HIV-1B RT in various functional and inhibited states have been reported over the past 22 years. These include structures in (i) unliganded form; (ii) in complex with various template-primers (T/P); (iii) $\mathrm{T} / \mathrm{P}$ and $\mathrm{dNTP}$; (iv) $\mathrm{T} / \mathrm{P}$ and NRTI-triphosphates (TP); (v) NNRTIs; or (vi) nucleic acid and NNRTIs [20-35].

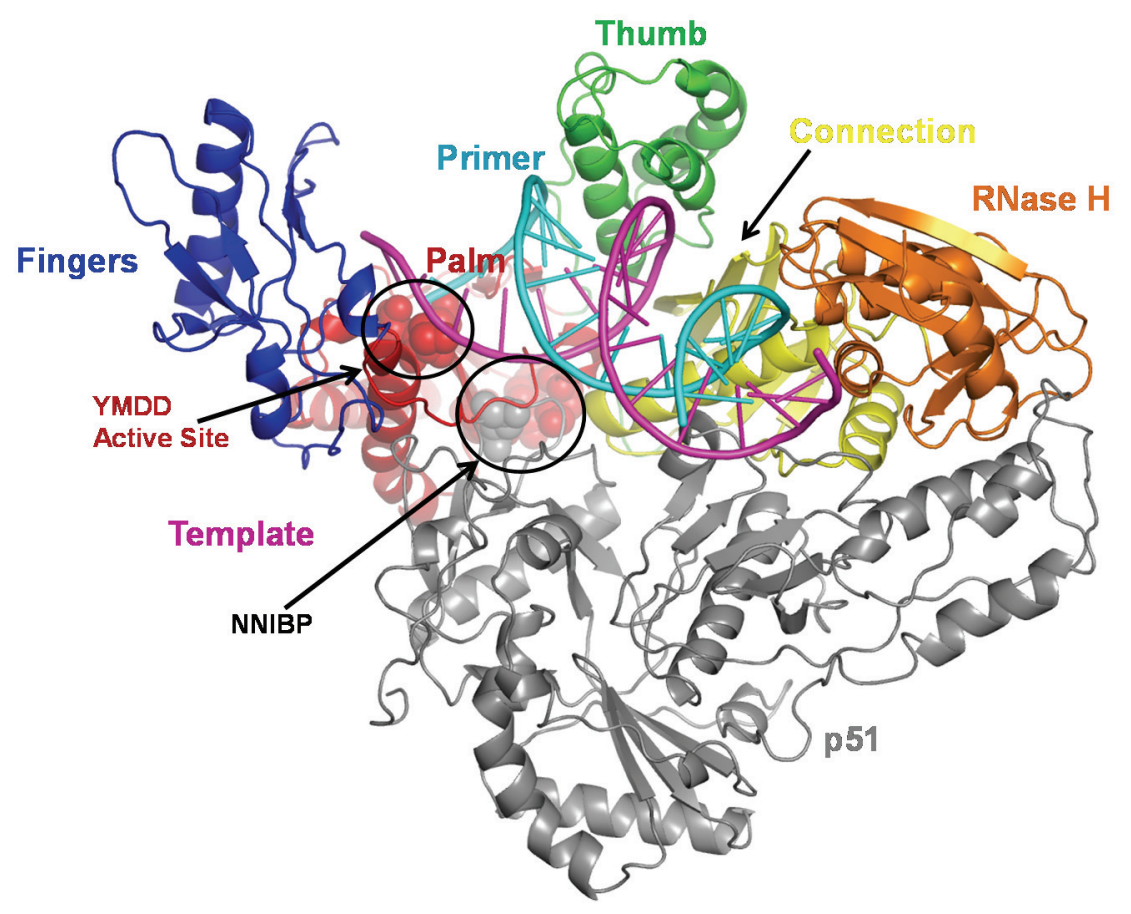


Figure 1. The crystal structure of HIV-1 RT bound to double stranded DNA. HIV-1 RT is a heterodimer of p66 and p51 subunits. Due to the resemblance of p66 to a half-open right hand, different subdomains in p66 have been named as the "palm" (red), fingers (blue), and thumb (green) [33]. The polymerase and RNase H (orange) activities are located in p66 subunit, and are linked by the connection subdomain (yellow). The p51 (dark gray) subunit is derived from proteolytic cleavage of the RNase $\mathrm{H}$ from $\mathrm{p} 66$ and has identical primary and secondary structure. However, the tertiary structure of p51 is markedly different than p66, leading to a non-functional arrangement of catalytic residues. The template/primer (magenta/cyan) binds in a DNA-binding cleft formed primarily by the p66 subunit. The active site (marked as YMDD) and the NNRTI binding pocket (NNIBP) are shown as spacefilled atoms. This figure was generated from Protein Data Bank file 2HMI [20]. This, as well as Figures 4 and 5, were generated using PyMOL program [36].

Structure(s) of HIV-non-B RTs have not been determined, although a structure of an unliganded HIV2 RT has been reported [37]. However, due to the high sequence conservation between HIV-1B and HIV-non-B RTs, the overall folding of HIV-non-B RT is expected to be similar. RT is an asymmetric heterodimer comprising two structurally distinct subunits (p66 and p51). The p66 subunit contains the active sites for the polymerase and RNase $\mathrm{H}$ activities of the enzyme. The $\mathrm{p} 51$ subunit, which is derived from p66 by protease-mediated cleavage of the RNase $\mathrm{H}$ domain plays a structural role [26,32,33], although some mutations in p51 have been reported to affect catalytic activity as well $[38,39]$.

The first anti-HIV drugs were nucleoside analogs lacking the 3'-OH group, which is required for DNA synthesis [40]. Currently, all approved NRTIs lack a 3'-OH (Figure 2), are phosphorylated in cells into dNTP analogs that bind at the dNTP-binding site [21,23,41,42], and act as chain terminators after their incorporation into viral DNA by RT $[40,43,44]$.

The second class of anti-HIV-1 RT drugs, (NNRTIs, Figure 3), bind in a hydrophobic pocket of HIV-1B RT at the base of the p66 thumb subdomain, $\sim 10 \AA$ away from the polymerase active site (Figure 1). NNRTI binding has multiple effects, including restriction of the p66 thumb subdomain's flexibility, and repositioning of the nucleic acid $[25,26,33,43,45,46]$.

\subsection{Mechanism of NRTI Resistance in HIV-1B}

In HIV-1B, major mutations associated with NRTI resistance are M41L, A62V, D67N, 69 insertions (T69S plus the addition of SS, SA, or SG), K70R/E, K65R, L74V, V75I, F77L, Y115F, F116Y, Q151M, M184V/I, L210W, T215Y/F, and K219Q/E (Figure 4) [47]. Of these, M41L, A62V, 69ins, K70R, L210W, T215Y/F, and K219Q/E form the 69 insertion complex. Mutations A62V, V75I, F77L, F116Y, and Q151M combine to form the Q151 complex, and mutations M41L, D67N, K70R, L210W, $\mathrm{T} 215 \mathrm{Y} / \mathrm{F}$ and $\mathrm{K} 219 \mathrm{Q} / \mathrm{E}$ are known as TAMs (thymidine-associated mutations) or EEMs (excisionenhancing mutations) [47]. The 69 insertion complex is associated with resistance to all approved NRTIs when present with one or more TAMs at codons 41, 210, or 215 [47,48]. The Q151 complex mutations confer reduced susceptibility to all NRTIs except TDF (tenofovir) [48] while the TAMs enhance resistance to all approved NRTIs $[49,50]$. 
<smiles></smiles>

AZT<smiles>O=c1nc[nH]c2c1ncn2C1CCC(CO)O1</smiles>

ddl<smiles>Cc1cn(C2CC3CC2O3)c(=O)[nH]c1=O</smiles>

d4T<smiles>Nc1ccn(C2CCC(CO)O2)c(=O)n1</smiles>

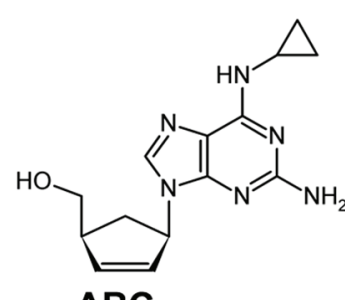

ABC<smiles></smiles>

FTC<smiles>CC(Cn1cnc2c(N)ncnc21)OCP(=O)([O-])[O-]</smiles>

TDF

Figure 2. FDA approved nucleoside/nucleotide inhibitors (NRTIs/NtRTIs) of HIV-1B RT: All approved NRTIs/NtRTIs (AZT, azidothymidine; d4T, stavudine; FTC, emtricitabine; ddC, zalcitabine; ddI, didanosine; ABC, abacavir; TDF, tenofovir) lack a 3'-OH group. After incorporation of NRTIs/NtRTIs into DNA by HIV-1B RT, they act as chain terminators. FTC is 5-fluoro derivative of 3TC; the latter is not included in this figure. All chemical structures in this article were drawn by ChemSketch 3.5 [51].<smiles></smiles><smiles>O=C1Nc2ccc(Cl)cc2C(C#CC2CC2)(C#CC2CC2)O1</smiles>

NVP<smiles>CC(C)Nc1cccnc1N1CCN(C(=O)c2cc3cc(NS(C)(=O)=O)ccc3[nH]2)CC1</smiles>

EFV<smiles>Cc1cc(C#N)cc(C)c1Oc1nc(Nc2ccc(C#N)cc2)nc(N)c1Br</smiles>

ETV

\section{DLV}<smiles>Cc1cc(/C=C/C#N)cc(C)c1Nc1ccnc(Nc2ccc(C#N)cc2)n1</smiles>

RPV 
Figure 3. FDA-approved NNRTIs: nevirapine (NVP), efavirenz (EFV), delavirdine (DLV), etravirine (ETV), and rilpivirine (RPV). Currently, DLV is not recommended by the US Department of Health and Human Services. ETV, RPV, and sometimes EFV, are referred to as second-generation NNRTIs.

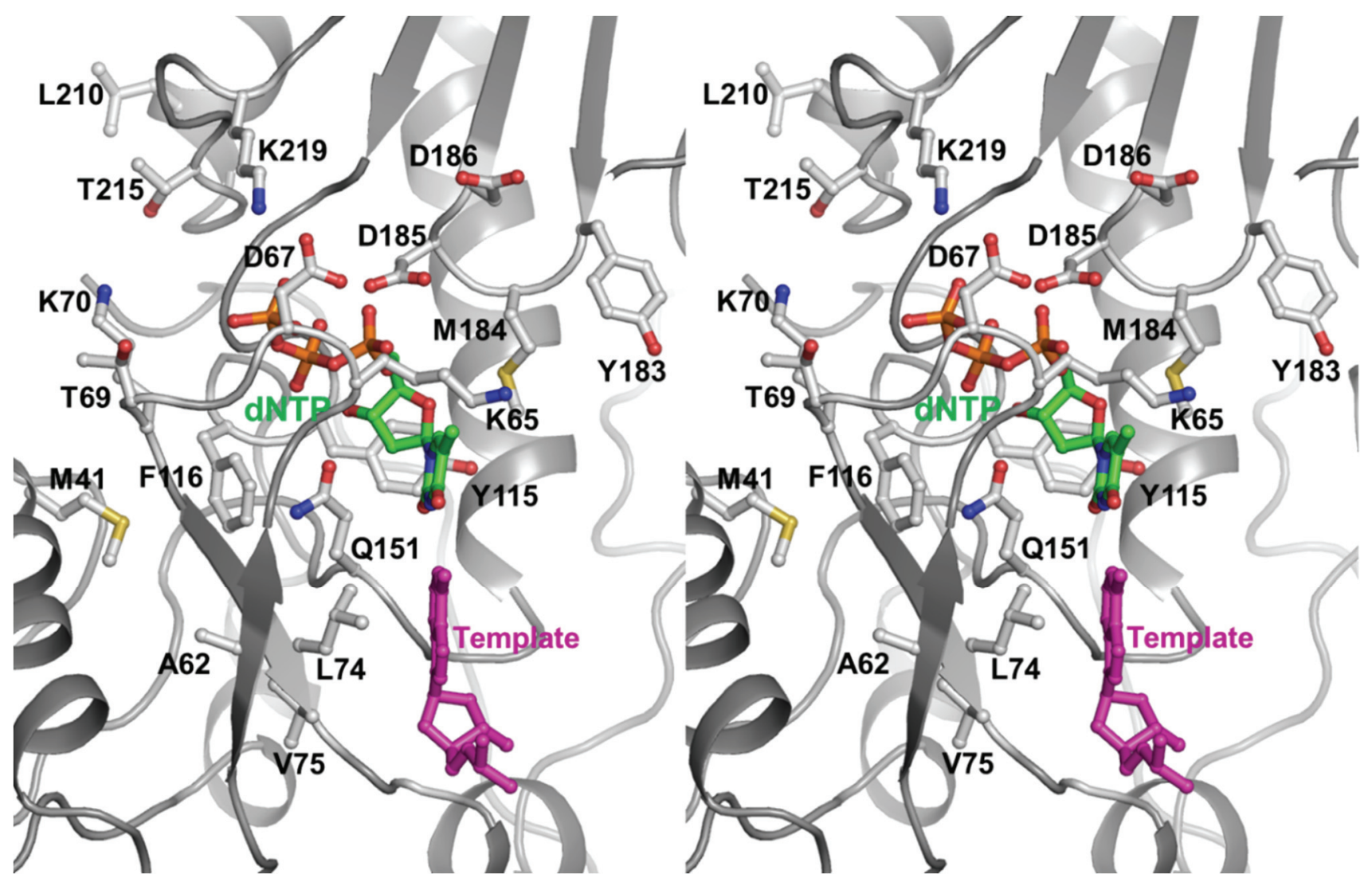

Figure 4. Stereoview of the polymerase active site of HIV-1B RT with residues involved in NRTI resistance. Amino acid residues, dNTP and template substrates are shown in ball-and-stick representation. The backbone of HIV-1 RT (PDB file 1RTD) [21] is shown in light gray ribbon representation. The amino acid side chains are colored by atom type (carbon, white; oxygen, red; nitrogen, blue; and sulfur, yellow). The dNTP is also colored by atom type but the carbon and phosphorus atoms are green and orange, respectively. The template nucleotide is colored magenta. For clarity, the position of F77 is not shown.

Mutations K65R, L74V, Y115F, and M184V are associated with resistance to abacavir (ABC), K65R and L74V are ddI-resistance mutations, K65R and M184V/I are resistant to FTC and 3TC, K65R and K70E are related to TDF resistance, and M41L, D67N, K70R, L210W, T215Y/F, and K219Q/E cause resistance to AZT [47].

Resistance to NRTIs is achieved by two distinct mechanisms in HIV-1B: (i) discrimination; and (ii) excision. In the discrimination mechanism, the mutations favor natural dNTP substrate over NRTI/NtRTI by decreasing binding affinity of NRTI-TP $\left(\mathrm{K}_{\mathrm{d}}\right)$, by reducing polymerization rate $\left(k_{\mathrm{pol}}\right)$, or both $[44,52-56]$. The mutations known to cause resistance using the discrimination mechanism are K65R, K70E, L74V, V75I, Q151M complex, and M184V/I [52,53,55,57-67]. Biochemical data show that most 
of these mutations reduce the polymerase rate $\left(k_{\mathrm{pol}}\right)$ and/or decrease the NRTI-TP binding affinity $\left(\mathrm{K}_{\mathrm{d}}\right)$ compared to the wild-type HIV-1B RT [40,43,52,53,55,57-67].

Using the excision mechanism, an EEM HIV-1B RT carries out ATP-mediated excision of NRTI from the 3'-end of the DNA primer chain and permits extension of the DNA $[57,68,69]$. This process is also referred to as "primer unblocking". AZT and d4T resistance mutations M41L, D67N, K70R, L210W, T215Y/F, and K219Q/E are the most common examples of EEMs. These residues are located outside the dNTP-binding site [21,23,24,40,43,70-72] and do not affect the incorporation of nucleotide analogs [56,73-77]. Instead, they facilitate the ATP-dependent removal of the incorporated NRTI-MP that is catalyzed by the same active site as the polymerization reaction but in the reverse direction $[69,70,78-83]$.

\subsection{NRTI-Associated Mutations in Different HIV-1 Subtypes}

A disparity in resistance mutations after NRTI treatment has been seen among HIV-1 subtypes. HIV-1C patients from Botswana who underwent AZT/ddI-containing HAART developed resistance predominantly through the $67 \mathrm{~N} / 70 \mathrm{R} / 215 \mathrm{Y}$ pathway [84]. These mutations are different than AZT/ddI-associated resistance mutations (TAM/EEM) in HIV-1B. In HIV-1B, AZT/ddI resistance is acquired through either a TAM1 (M41L, L210W and T215Y) or a TAM2 (D67N, K70R and K219E/Q) pathway. A different set of mutations was selected in HIV-1C infected patients in India [85] under the same treatment protocol. While most of the NRTI-resistance mutations in the Indian patients were similar to those in HIV-1B (TAM1 and TAM2), they also harbored additional RT mutations A98G, E203D/K/V/N/A, H208Y, and H221Y [85]. Similarly, an entirely different resistance pattern was seen in HIV-1C infected patients from Malawi and South Africa who received first-line treatment with $\mathrm{d} 4 \mathrm{~T} / 3 \mathrm{TC} / \mathrm{NVP}[86,87]$. Not surprisingly, the most prevalent NRTI-associated mutation in these patients was M184V (81\%), which is associated with 3TC treatment. Interestingly, 23\% of the patients acquired the $\mathrm{K} 70 \mathrm{E}$ or K65R mutations that are associated with TDF resistance even though the patients were not exposed to TDF [86]. Results from another study in Botswana also showed high incidences of the K65R mutation (30\%) in HIV-1C patients who received combinations of either $\mathrm{d} 4 \mathrm{~T} / \mathrm{ddI} / \mathrm{NVP}$ or d4T/ddI/EFV [88]. The K65R mutation was detected in $7 \%$ and $15 \%$ of patients in South Africa failing first- and second-line regimens, respectively [89-91]. The nucleoside backbone in these treatments included $\mathrm{d} 4 \mathrm{~T} / 3 \mathrm{TC}$ or ddI/AZT [90,91]. The K65R mutation in HIV-1C was also seen in Ethiopian and Indian patients $(10 \%-12 \%)$ who failed d4T/3TC/NVP therapy [92,93]. These results suggest that the K65R substitution may emerge at a higher frequency among individuals infected with HIV-1C viruses who are receive d4T/3TC-based first-line therapy, and the introduction of TDF-based regimens may show limited success [9].

The K65R mutation has been shown to be selected faster in HIV-1C than in HIV-1B when tenofovir (TDF) is used as one of the nucleoside drugs [7]. On the contrary, K65R appears to be less frequent in HIV-1A than other subtypes [94]. Some subtype-dependent differences in K65R or TAM mutations can be attributed to treatment regimens, disease stage and access to viral load testing in different developing countries [94]. The faster acquisition of K65R in HIV-1C has also been linked to the nature of the HIV1CRNA template [95-97]. 


\subsection{NNRTI-Associated Mutations in Different HIV-1 Subtypes}

EFV and NVP are two NNRTIs that have been widely used in both developed and resource-limited countries. However, both NNRTIs have a low genetic barrier [98]. A single mutation in the NNRTI binding pocket is sufficient to cause clinical failure [98]. Moreover, a high level of crossresistance between NVP and EFV [99] has limited available therapeutic options. ETV and RPV are second generation NNRTIs that are effective against common NVP and/or EFV resistant HIV-1 viruses [100-102]. NNRTIs bind to a hydrophobic pocket (non-nucleoside inhibitor binding pocket or NNIBP) formed by residues $95,100,101,103,106,108,179,181,188,190,227,229,234,236$, and 318 from the p66 subunit and 138 from the p51 subunit (Figure 5) [27,30,45]. NNRTI resistance can be achieved by two different mechanisms: (i) affecting the entry/release $\left(k_{o n} / k_{o f f}\right)$ of NNRTI to and from the NNIBP (e.g., K103N and E138K mutations) [38,103-107]; and (ii) altering the NNIBP geometry, thus directly affecting interactions with the inhibitor (e.g., Y181C and Y188L) [27,29,72,108,109].

The NNRTIs are used by themselves and in combination with two NRTIs. Similar to diverse mutation pattern in response to NRTI treatment, different patterns of NNRTI-resistance mutations have been reported for different HIV subtypes. Single-dose NVP treatment, often used for prevention of motherto-child transmission (PMTCT) in countries with limited resources, has shown a wide range of subtypedependent resistance patterns. Resistance to NVP monotherapy in HIV-1C, HIV-1D, HIV1-A and HIV1 CRF02_AG infections has been reported to be $69 \%, 36 \%, 19 \%$, and $21 \%$, respectively [110]. Similarly, a meta-analysis in South African HIV-1C patients treated for PMTCT showed that 35.7\% of women and $52.6 \%$ of children carried virus with NVP-resistance mutations [111]. Results from a Ugandan cohort showed that HIV-1C was more NVP resistant than HIV-1D and HIV-1A [112]. The K103N mutation most frequently appeared in mothers, while the Y181C mutation was predominant in children [113]. These results clearly demonstrate that the response to NVP monotherapy (as for PMTCT) significantly varies among HIV subtypes.

During in vitro serial passages of HIV-1C in NVP or EFV, the virus developed the V106M mutation, in addition to the V106A mutation, which is commonly selected in HIV-1B [114]. This difference has been attributed to a nucleotide polymorphism at position 106 of RT [18]. The clinical importance of V106M in HIV-non-B subtypes has been confirmed in many studies, which show that V106M emerges frequently in patients infected with HIV-1C and HIV-1 CRF01_AE viruses during therapy with NVP or EFV $[80,84,85,115-118]$. It should be noted that, similar to residue 106, additional silent drug-resistant RT mutations at residues 65, 138, and 161 were reported in Ethiopian isolates and subtype C reference strains [114]. 


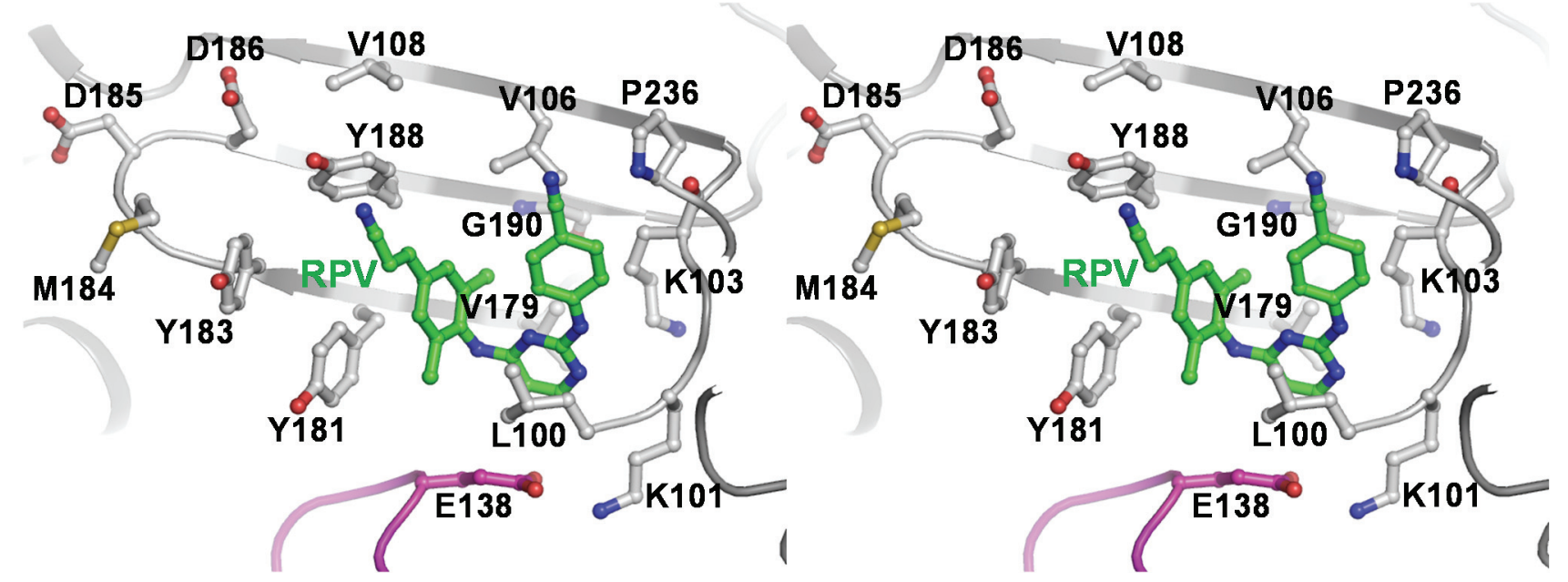

Figure 5. Amino acids involved in HIV-1B NNRTI resistance: Stereoview of HIV-1B RT with RPV bound at the NNIBP and NNRTI-resistance residues and RPV shown in ball-and-stick representation. The RT backbone (PDB file 2ZD1) [30] is shown in ribbon representation (p66 in light gray and p51 in magenta). Amino acid side chains are colored with carbon in white, oxygen in red, nitrogen in blue, and sulfur in yellow. RPV carbons are shown in green and nitrogens in blue. RPV resistance residue E138 [103,104,119-121] is shown in magenta. Residues 227, 229, and 234 are omitted for clarity.

Data from the DUET-1 and DUET-2 phase III clinical trials revealed a total of 17 ETV resistance-associated mutations (RAMs) (V90I, A98G, L100I, K101E/H/P, V106I, E138A, V179D/F/T, $\mathrm{Y} 181 \mathrm{C} / \mathrm{I} / \mathrm{V}, \mathrm{G} 190 \mathrm{~A} / \mathrm{S}$, and M230L) [100,101]. Three or more of these mutations were associated with decreased virological response to ETV [122]. V90I and E138A were the most prevalent mutations in HIV-1 CRF02_AG and HIV-1A1, while V106I was most prevalent in HIV-1C and HIV-1D. Biochemical data showed that E138A in combination with V179E and Y181C had increased resistance to ETV by five-fold and 11-fold, respectively [122]; however, none of the dual mutation samples were found to be ETV resistant [122].

In vitro serial passages of HIV-1B, HIV-1C, and HIV-1 CRF02_AG in ETV showed distinct patterns of resistance mutations [123]. HIV-1C acquired the V90I, V106M, E138K, V179D/E, Y181C, G190E/G, M230L, and K238N mutations. These mutations also emerged in HIV-1 CRF02_AG. However, in addition to the above mutations (except for M230L), ETV also selected K101Q, V189I, and H221Y in HIV-1B. Interestingly, the K103N/Q mutations were selected in HIV-1B and HIV-1 CRF02_AG, but not in HIV-1C.

In low- and middle- income countries (LMICs) where phenotyping and genotyping is not widely available and where non-B strains dominate, the patients' failure to a treatment regimen is always monitored either by immunological criteria ( $\mathrm{CD} 4^{+} \mathrm{T}$-cell counts) or manifestation of clinical symptoms. In such cases, extensive cross-resistance is observed, even when NVP and EFV are replaced with the second generation NNRTI etravirine (ETV). A study from India reported that in a failing regimen including NVP or EFV, 40\% of the HIV-1C infected patients had at least partial resistance to ETV [124]. Similar observations were reported in another Indian study where the HIV-1C-infected patients were treated with NVP/EFV for one to eight years and 45\% were resistant to ETV [93]. 
A group of 17 mutations, L100I, K101E/P, E138A/G/K/Q/R, V179L, Y181C/I/V, Y188L, H221Y, F227C, and M230I/L, have been defined as RPV RAMs [47,125-128]. The prevalence of these mutations among RPV treatment-naïve (but treated with NRTI+PI or NRTI+NNRTI regimens) patients infected with HIV-1B and HIV-non-B has been reported [125]. Nearly 5\% of the patients harbored primary RPV mutations. E138A was the most prevalent mutation (3.2\%) followed by E138K, H221Y, E138G, Y181C, and Y188L in HIV-1C. The distribution of RPV RAMs was significantly different between HIV-1B (2\%) and HIV-non-B (5\%) subtype patients [125]. This difference can be attributed to E138A, which is a known polymorphism mutation (6\%-8\%) in HIV-1C virus [129].

Despite the structural similarity between ETV and RPV, both being DAPY (diarylpyrimidine) derivatives, different sets of resistance mutations have been reported for the same HIV-non-B (HIV-CRF01_AE) infection. The mutations Y181C, G190A, and K103N emerged in patients who failed ETV therapy, whereas mutations K101P, Y181I, and Y181V were predominantly seen in patients who failed RPV [130]. Notably, the patients who failed RPV therapy were resistant to ETV even though ETV RAMs were not found among these patients [125,130]. Many other NNRTI-resistance mutations that vary from subtype to subtype have been reported. A list of these mutations has been is given in Table 1. In some subtypes, resistance to given NNRTI(s) has been attributed to a high degree of polymorphism. For example, A98S mutation, which is resistant to all NNRTIs in HIV-1B and HIV-1C (Table 1) may confer resistance to NNRTIs in HIV-1G due to high polymorphism in this subtype [131].

Table 1. NNRTI-resistance mutations in response to NNRTI treatment among different HIV subtypes (modified from Santoro and Perno, [132]).

\begin{tabular}{ccclc}
\hline Mutation & Subtype & NNRTIs & \multicolumn{1}{c}{ Comment } & Reference \\
\hline K103N & $\begin{array}{c}\text { B, C, F, } \\
\text { CRF02_AE }\end{array}$ & $\begin{array}{c}\text { EFV, DLV }, \\
\text { NVP }\end{array}$ & $\begin{array}{l}\text { K103 appears with low frequency } \\
\text { in C compared to B, F and } \\
\text { CRF02_AE }\end{array}$ & {$[133-136]$} \\
\hline V106M & $\begin{array}{c}\text { B, C and } \\
\text { CRF01_AE }\end{array}$ & EFV, NVP & $\begin{array}{l}\text { V106M emerges frequently in C } \\
\text { due to low genetic barrier compared } \\
\text { to B and CRF01_AE }\end{array}$ & {$[99,114,118]$} \\
\hline E138K & $\begin{array}{c}\text { B, C, } \\
\text { CRF02_AG }\end{array}$ & ETR & $\begin{array}{l}\text { First emerges in B, C and } \\
\text { CRF02_AG. Preferential selection } \\
\text { in B is Y181C }\end{array}$ & {$[80,123]$} \\
\hline G190A & C & All NNRTIs & $\begin{array}{l}\text { This mutation in C may be due to } \\
\text { high G190A/S polymorphism in C }\end{array}$ & {$[118]$} \\
\hline Y181C & A, B & ETR & $\begin{array}{l}\text { Preferential selection under drug } \\
\text { pressure on A and B subtypes }\end{array}$ & {$[80]$} \\
\hline $\begin{array}{c}\text { Y181C } \\
\text { and }\end{array}$ & C & EFV, DLV, & High frequency in C & {$[133-136]$} \\
\hline N348I & C & ETR & High frequency in C at ETR failure & {$[137,138]$} \\
\hline N348I & B & NVP & High frequency in B at NVP failure & {$[11,12]$} \\
\hline
\end{tabular}




\subsection{Mutations that Impact both Classes of RTIs (Connection Subdomain Mutations)}

Until recently, all HIV-1 drug-resistance testing kits interrogated $\sim 250 \mathrm{~N}$-terminal amino acids of HIV-1 RT. These testing kits were based on the assumption that all currently approved RTIs target the polymerase domain of RT, and mutations in the domain confer drug resistance. One group of researchers from Japan, in collaboration with us [11] and another group from Australia [12], independently showed that the connection subdomain mutation N348I causes resistance to both classes of drugs (NRTIs and NNRTIs) in HIV-1B and HIV-1D patients. Biochemical data showed that N348I, by itself or in combination with TAMs, reduces the rate of RNA template degradation by RT $[12,139]$. We used transient-state kinetics to decipher the contribution of N348I in the polymerase function of RT and resistance to NVP [38]. We demonstrated that the N348I mutation increases the processivity of RT and enhances NVP dissociation from the NNIBP [38]. A molecular dynamics modeling study proposes that N348I contributes to NVP resistance through a long-range allosteric communication network between the connection and NNIBP [140]. More recently, Brehm et al. [138] reported the presence of the N348I mutation in HIV-1C patients who failed d4T/3TC/NVP or d4T/3TC/EFV therapy. A group of drug-resistance mutations in the connection subdomain of RT (A376S, A400T, Q334D, G335D, N348I, and $\mathrm{A} 371 \mathrm{~V})$ in a Brazilian cohort (HIV-1C) was recently identified using single genome sequencing methodology [141]. The connection subdomain mutations identified in this study were similar to those previously reported in subtype B. However, the data showed that these mutations enhanced resistance to ETV by six- to 11-fold in the presence of L100I/K103N/Y181C (NNRTI) and TAM-associated mutations [141]. A detailed kinetic characterization of connection subdomain mutations in HIV-non-B needs to be performed before one can establish whether their mechanism of inhibition and resistance is similar to that in HIV-1B.

\section{Transmitted Drug Resistance (TDR) in HIV-Non-B}

Transmitted drug resistance (TDR) is defined as resistance to one or more ARVs in individuals with no previous drug exposure, and it is presumed to be the result of the direct transmission of resistant strains from treated individuals [43]. TDR can be complicated by the presence of drug resistance mutations in a given subtype that may exist as polymorphisms in some other subtype. Both TDR and polymorphisms can lead to ART failure in treatment-naïve patients and limit the efficacy of drug regimens. In regions of the world where HAART has been used for several years, TDR can be found in up to $25 \%$ of HIV infected individuals [128,142-144]. The most commonly reported NRTI TDR mutations in HIV-1B are M184V and M184I. Other TDR mutations are M41L, K219E/N/Q/R, and $\mathrm{T} 215 \mathrm{~F} / \mathrm{Y}$ and 215 revertant mutations (T215D/C/E/S/I/V) [145,146]. Transmission of M184V has also been reported in HIV-non-B [143] cases with high-level resistance to 3TC and FTC. The most common HIV-non-B TDR mutations are K103N, Y181C/I, and Y188C/H/L [143,144,147,148].

\section{Polymorphisms in HIV-Non-B}

A polymorphism is a nucleotide variation from the consensus sequence within a subtype, arbitrarily defined as a position-specific difference occurring in $>1 \%$ of sequences [147]. Biochemical and virological data have demonstrated that polymorphisms can affect the magnitude of resistance conferred by known 
resistance mutations $[10,11,15,148,149]$, not only in different HIV-1 subtypes but also in different HIV types. For example, HIV-2 and group O viruses have high-level innate resistance to NNRTIs because of drug-resistance polymorphisms [150,151]. Of the first 240 amino acid residues of HIV-1 RT, polymorphisms at 41 positions in HIV-1A (17\%), 45 in HIV-1B (19\%), 56 in HIV-1C (23\%), 43 in HIV1D (18\%), 35 in HIV-1F (15\%), 32 in HIV-1G (13\%), 46 in HIV-1 CRF01_AE (19\%), and 56 in HIV-1 CRF021_AG (23\%) have been reported based on testing of drug-naïve HIV-infected individuals $[131,147]$. Subtype-specific polymorphisms at residue positions that are related to NRTI and NNRTI drug resistance are shown in Table 2.

Table 2. Polymorphism at drug resistance positions in RT from untreated patients (modified from Kantor and Katzenstein, [147]).

\begin{tabular}{cccc}
\hline Subtype & $\begin{array}{c}\text { Subtype Reference } \\
\text { Sequences }\end{array}$ & $\begin{array}{c}\text { RT Sequence PM Position, } \\
\text { NRTI RAMs }\end{array}$ & $\begin{array}{c}\text { RT Sequence PM Position, } \\
\text { NNRTI RAMs }\end{array}$ \\
\hline A & U455 & A62V, V118I & E138A, V179I/T, K238R \\
B & HXB2 & V118I & A98S, V179I/D/E \\
C & C2220 & V118I & A98S, E138A, V179I \\
D & NDK & V118I (comparable to B) & V179I \\
F & $93 B R 020$ & V41I, M184V & E138A/G, V179I/D \\
G & SE6165 & & A98S, V179E \\
CRF01_AE & CM240 & V41I, A62V & V75L, V106I, V179I/D \\
CRF02_AG & IbNG & V41I, V118I & V106I, V179I \\
\hline
\end{tabular}

It is now well established that connection subdomain mutations are associated with low-level resistance to NNRTIs [11,12,152]. Several connection subdomain mutations are polymorphic in HIV-non-B [153-155]. Polymorphisms G335D and A371V in HIV-1 CRF01_AE showed significantly reduced susceptibility to NRTIs and NNRTIs [154]. In a Brazilian HIV-1C cohort, polymorphisms G335D, A376S, and A400T/S have been reported [153]. However, more data from different HIV-non-B subtypes are required to establish the effect of polymorphisms on drug susceptibility and drug resistance.

\section{Therapeutic Response in HIV-Non-B subtypes in the Presence of Drug Resistance Mutations}

Several clinical studies have provided evidence of viral re-suppression despite the presence of major drug-resistance mutations (DRMs) in HIV-1C. A South African study showed that despite the presence of key NNRTI mutations like K103N, V106M, or G190A, a portion of patients achieved viral re-suppression [156]. This was further supported by a report from another South African cohort where, in nine of 12 viremic patients, HIV-1C was suppressed even in the presence of major DRMs, such as $\mathrm{K} 103 \mathrm{~N}$ or M184V [157]. A recent study from India, where HIV-1C is the prevalent subtype, reported that three patients had controlled viremia in the presence of multiple major NRTI and NNRTI resistance-associated mutations (M184V+G190A; M184V+K103N; M184V+Y181C) without change in therapy; the patients maintained $>95 \%$ adherence both before and after the viral rebound as well as $\mathrm{CD}^{+} \mathrm{T}$-cell counts in the normal range [158]. Collectively, these studies support the idea that further work is needed to understand how DRMs phenotypically affect viral fitness, drug susceptibility, and patients' therapeutic responses. 


\section{Future Perspectives: New Class of NRTIs}

The combination of NRTIs currently in use can limit treatment efficacy in many ways [159]. For example, AZT and d4T share the same excision pathway and therefore combining the two drugs can produce suboptimal results. Similarly, drug-drug interactions such as those reported between abacavir $(\mathrm{ABC})$ and other protease inhibitors (atazanavir/ritonavir or lopinavir/ritonavir) may also impact the outcome of some combination therapies [160]. The low genetic barrier of NNRTIs, higher polymorphism in NNIBP of HIV-non-B subtypes, and extensive cross-resistance to second generation NNRTIs after failure to first generation NNRTIs may present challenges for use of NNRTI-containing combinations in some cases. NRTIs that act by novel inhibition mechanisms, which can be used synergistically with current drugs to improve resistance profiles, are continuously pursued. The chemical structure of some new NRTIs, which are either in pre-clinical development or at various stages of clinical trials, are shown in Figure 6. Amdoxovir is a prodrug of $\beta$-D-dioxolane guanosine (DXG), currently evaluated in phase II clinical trials. Apricitabine (ATC) is in phase IIb clinical trials and it has been shown to be effective against HIV-1 viruses containing M184V, L74V, and TAMs [161].

Several 4'-substituted NRTIs have been reported to be potent antivirals [103,162,163]. Among them, 4'-ethynyl-2-fluoro-2'-deoxyadenosine (EFdA) (Figure 6) is the most potent that can inhibit RT as a translocation-defective RT inhibitor or as a delayed chain terminator, depending on the sequence of the template/primer substrate $[164,165]$. These compounds contain an ethynyl group modification at the $4^{\prime}$ position of the sugar moiety that appears to make extensive interactions in a hydrophobic pocket of the RT polymerase active site and block the translocation of RT after their incorporation into the nascent DNA chain [163]. EFdA inhibits efficiently essentially all drug-resistant strains [166], and displays low mitochondrial toxicity due to the fact that it is a poor substrate for DNA polymerase $\gamma[164,167]$. The effect of these new NRTIs on HIV-non-B subtypes is yet to be determined.

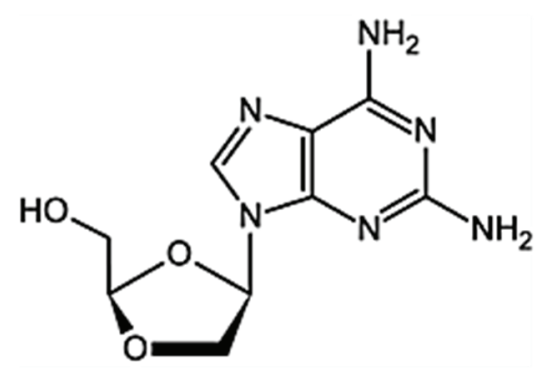

Amdoxovir<smiles>Nc1nc(=O)n(C2C=CC(CO)O2)cc1F</smiles>

Elvucitabine<smiles>C[C@H]1C[C@@H](n2ccc(N)nc2=O)[C@@H](CO)O1</smiles><smiles>C#C[C@]1(CO)O[C@@H](n2cnc3c(N)nc(F)nc32)C[C@@H]1O</smiles>

EFdA 
Figure 6. NRTIs in clinical trials or pre-clinical development. Amdoxovir, apricitabine, and elvucitabine are being developed by RFS Pharma, Avexa Pharmaceuticals, and Achillion Pharmaceuticals, respectively. EFdA has been licensed by Merck from Yamasa Corporation. With the exception of EFdA, these compounds lack a 3'-OH and function as chain terminators. EFdA contains a 3'-OH and blocks viral replication by multiple mechanisms, including by acting as a translocation-deficient reverse transcriptase inhibitor $[103,163,164,168]$.

\section{Conclusions}

In summary, the available biochemical, virological and clinical data on HIV-1B and HIV-non-B indicate that the genetic diversity among HIV-1 subtypes can impact the outcome of ART. As HAART becomes more accessible to more patients in resource-limited settings, a better picture of susceptibility and resistance is expected to emerge. These results may influence (i) the formulation of currently approved drugs and drug combinations to improve efficacy and adherence in HIV-non-B infected patients and (ii) the development of more potent and broad-spectrum NRTIs and NNRTIs.

\section{Acknowledgments}

This work was supported, in whole or in part, by National Institutes of Health grants AI076119, AI099284, AI100890, AI112417, and GM103368 (SGS); R37 AI27690 (MERIT Award) and P50 GM103368 to EA; AI079801 to (MAP) and Swedish International Developing Agency, CHAIN FP7 EU, the Swedish Civil Contingencies Agency SWE-2009-151, and the Swedish Research Council 521-2012-3476 and 2007-7092 to AS. We also acknowledge support from Ministry of Knowledge and Economy, Bilateral International Collaborative R\&D Program, Republic of Korea and the financial support from Mizzou Advantage program of University of Missouri (SGS).

\section{Conflicts of Interest}

Authors declare no conflict of interest.

\section{References and Notes}

1. Plantier, J.C.; Leoz, M.; Dickerson, J.E.; de Oliveira, F.; Cordonnier, F.; Lemee, V.; Damond, F.; Robertson, D.L.; Simon, F. A new human immunodeficiency virus derived from gorillas. Nat. Med. 2009, 15, 871-872.

2. Robertson, D.L.; Anderson, J.P.; Bradac, J.A.; Carr, J.K.; Foley, B.; Funkhouser, R.K.; Gao, F.; Hahn, B.H.; Kalish, M.L.; Kuiken, C.; et al. HIV-1 nomenclature proposal. Science 2000, 288, 5556.

3. Ward, M.J.; Lycett, S.J.; Kalish, M.L.; Rambaut, A.; Leigh Brown, A.J. Estimating the rate of intersubtype recombination in early HIV-1 group M strains. J. Virol. 2013, 87, 1967-1973.

4. Hemelaar, J.; Gouws, E.; Ghys, P.D.; Osmanov, S.; WHO-UNAIDS Network for HIV Isolation and Characterisation. Global trends in molecular epidemiology of HIV-1 during 2000-2007. AIDS 2011, 25, 679-689. 
5. Los Alamos National Laboratory. HIV Circulating Recombinant Forms (CRFs). Available online: http://www.hiv.lanl.gov/content/sequence/HIV/CRFs/CRFs.html (accessed on 15 September 2014).

6. Vidal, N.; Peeters, M.; Mulanga-Kabeya, C.; Nzilambi, N.; Robertson, D.; Ilunga, W.; Sema, H.; Tshimanga, K.; Bongo, B.; Delaporte, E. Unprecedented degree of human immunodeficiency virus type 1 (HIV-1) group M genetic diversity in the Democratic Republic of Congo suggests that the HIV-1 pandemic originated in Central Africa. J. Virol. 2000, 74, 10498-10507.

7. Brenner, B.G. Resistance and viral subtypes: How important are the differences and why do they occur? Curr. Opin. HIV AIDS 2007, 2, 94-102.

8. Phillips, A.N.; Dunn, D.; Sabin, C.; Pozniak, A.; Matthias, R.; Geretti, A.M.; Clarke, J.; Churchill, D.; Williams, I.; Hill, T.; et al. Long term probability of detection of HIV-1 drug resistance after starting antiretroviral therapy in routine clinical practice. AIDS 2005, 19, 487-494.

9. Wainberg, M.A.; Brenner, B.G. Role of HIV Subtype Diversity in the Development of Resistance to Antiviral Drugs. Viruses 2010, 2, 2493-2508.

10. Hachiya, A.; Marchand, B.; Kirby, K.A.; Michailidis, E.; Tu, X.; Palczewski, K.; Ong, Y.T.; Li, Z.; Griffin, D.T.; Schuckmann, M.M.; et al. HIV-1 Reverse Transcriptase (RT) Polymorphism 172K Suppresses the Effect of Clinically Relevant Drug Resistance Mutations to Both Nucleoside and Non-nucleoside RT Inhibitors. J. Biol. Chem. 2012, 287, 29988-29999.

11. Hachiya, A.; Kodama, E.N.; Sarafianos, S.G.; Schuckmann, M.M.; Sakagami, Y.; Matsuoka, M.; Takiguchi, M.; Gatanaga, H.; Oka, S. Amino acid mutation N348I in the connection subdomain of human immunodeficiency virus type 1 reverse transcriptase confers multiclass resistance to nucleoside and nonnucleoside reverse transcriptase inhibitors. J. Virol. 2008, 82, 3261-3270.

12. Yap, S.H.; Sheen, C.W.; Fahey, J.; Zanin, M.; Tyssen, D.; Lima, V.D.; Wynhoven, B.; Kuiper, M.; Sluis-Cremer, N.; Harrigan, P.R.; et al. N348I in the connection domain of HIV-1 reverse transcriptase confers zidovudine and nevirapine resistance. PLoS Med. 2007, 4, e335.

13. Betancor, G.; Puertas, M.C.; Nevot, M.; Garriga, C.; Martinez, M.A.; Martinez-Picado, J.; Menendez-Arias, L. Mechanisms involved in the selection of HIV-1 reverse transcriptase thumb subdomain polymorphisms associated with nucleoside analogue therapy failure. Antimicrob. Agents Chemother. 2010, 54, 4799-4811.

14. Wright, D.W.; Deuzing, I.P.; Flandre, P.; van den Eede, P.; Govaert, M.; Setiawan, L.; Coveney, P.V.; Marcelin, A.G.; Calvez, V.; Boucher, C.A.; et al. A polymorphism at position 400 in the connection subdomain of HIV-1 reverse transcriptase affects sensitivity to NNRTIs and RNaseH activity. PLoS One 2013, 8, e74078.

15. Kearney, M.; Palmer, S.; Maldarelli, F.; Shao, W.; Polis, M.A.; Mican, J.; Rock-Kress, D.; Margolick, J.B.; Coffin, J.M.; Mellors, J.W. Frequent polymorphism at drug resistance sites in HIV-1 protease and reverse transcriptase. AIDS 2008, 22, 497-501.

16. Kemp, S.D.; Shi, C.; Bloor, S.; Harrigan, P.R.; Mellors, J.W.; Larder, B.A. A novel polymorphism at codon 333 of human immunodeficiency virus type 1 reverse transcriptase can facilitate dual resistance to zidovudine and L-2',3'-dideoxy-3'-thiacytidine. J. Virol. 1998, 72, 5093-5098.

17. Delviks-Frankenberry, K.A.; Nikolenko, G.N.; Pathak, V.K. The "Connection" between HIV drug resistance and RNase H. Viruses 2010, 2, 1476-1503. 
18. Wainberg, M.A.; Brenner, B.G. The impact of HIV genetic polymorphisms and subtype differences on the occurrence of resistance to antiretroviral drugs. Mol. Biol. Int. 2012, 2012, 256982.

19. Chen, R.; Quinones-Mateu, M.E.; Mansky, L.M. Drug resistance, virus fitness and HIV-1 mutagenesis. Curr. Pharm. Des. 2004, 10, 4065-4070.

20. Ding, J.; Das, K.; Hsiou, Y.; Sarafianos, S.G.; Clark, A.D., Jr.; Jacobo-Molina, A.; Tantillo, C.; Hughes, S.H.; Arnold, E. Structure and functional implications of the polymerase active site region in a complex of HIV-1 RT with a double-stranded DNA template-primer and an antibody Fab fragment at 2.8 A resolution. J. Mol. Biol. 1998, 284, 1095-1111.

21. Huang, H.; Chopra, R.; Verdine, G.L.; Harrison, S.C. Structure of a covalently trapped catalytic complex of HIV-1 reverse transcriptase: Implications for drug resistance. Science 1998, 282, 1669-1675.

22. Sarafianos, S.G.; Das, K.; Tantillo, C.; Clark, A.D., Jr.; Ding, J.; Whitcomb, J.M.; Boyer, P.L.; Hughes, S.H.; Arnold, E. Crystal structure of HIV-1 reverse transcriptase in complex with a polypurine tract RNA:DNA. EMBO J. 2001, 20, 1449-1461.

23. Tuske, S.; Sarafianos, S.G.; Clark, A.D., Jr.; Ding, J.; Naeger, L.K.; White, K.L.; Miller, M.D.; Gibbs, C.S.; Boyer, P.L.; Clark, P.; et al. Structures of HIV-1 RT-DNA complexes before and after incorporation of the anti-AIDS drug tenofovir. Nat. Struct. Mol. Biol. 2004, 11, 469-474.

24. Das, K.; Bandwar, R.P.; White, K.L.; Feng, J.Y.; Sarafianos, S.G.; Tuske, S.; Tu, X.; Clark, A.D., Jr.; Boyer, P.L.; Hou, X.; et al. Structural basis for the role of the K65R mutation in HIV-1 reverse transcriptase polymerization, excision antagonism, and tenofovir resistance. J. Biol. Chem. 2009, 284, 35092-35100.

25. Das, K.; Martinez, S.E.; Bauman, J.D.; Arnold, E. HIV-1 reverse transcriptase complex with DNA and nevirapine reveals non-nucleoside inhibition mechanism. Nat. Struct. Mol. Biol. 2012, 19, 253-259.

26. Jacobo-Molina, A.; Ding, J.; Nanni, R.G.; Clark, A.D., Jr.; Lu, X.; Tantillo, C.; Williams, R.L.; Kamer, G.; Ferris, A.L.; Clark, P.; et al. Crystal structure of human immunodeficiency virus type 1 reverse transcriptase complexed with double-stranded DNA at 3.0 A resolution shows bent DNA. Proc. Natl. Acad. Sci. USA 1993, 90, 6320-6324.

27. Ren, J.; Esnouf, R.; Garman, E.; Somers, D.; Ross, C.; Kirby, I.; Keeling, J.; Darby, G.; Jones, Y.; Stuart, D.; et al. High resolution structures of HIV-1 RT from four RT-inhibitor complexes. Nat. Struct. Biol. 1995, 2, 293-302.

28. Unge, T.; Knight, S.; Bhikhabhai, R.; Lovgren, S.; Dauter, Z.; Wilson, K.; Strandberg, B. 2.2 A resolution structure of the amino-terminal half of HIV-1 reverse transcriptase (fingers and palm subdomains). Structure 1994, 2, 953-961.

29. Ren, J.; Milton, J.; Weaver, K.L.; Short, S.A.; Stuart, D.I.; Stammers, D.K. Structural basis for the resilience of efavirenz (DMP-266) to drug resistance mutations in HIV-1 reverse transcriptase. Structure 2000, 8, 1089-1094.

30. Das, K.; Bauman, J.D.; Clark, A.D., Jr.; Frenkel, Y.V.; Lewi, P.J.; Shatkin, A.J.; Hughes, S.H.; Arnold, E. High-resolution structures of HIV-1 reverse transcriptase/TMC278 complexes: Strategic flexibility explains potency against resistance mutations. Proc. Natl. Acad. Sci. USA 2008, 105, 1466-1471. 
31. Pata, J.D.; Stirtan, W.G.; Goldstein, S.W.; Steitz, T.A. Structure of HIV-1 reverse transcriptase bound to an inhibitor active against mutant reverse transcriptases resistant to other nonnucleoside inhibitors. Proc. Natl. Acad. Sci. USA 2004, 101, 10548-10553.

32. Hsiou, Y.; Ding, J.; Das, K.; Clark, A.D., Jr.; Hughes, S.H.; Arnold, E. Structure of unliganded HIV-1 reverse transcriptase at 2.7 A resolution: Implications of conformational changes for polymerization and inhibition mechanisms. Structure 1996, 4, 853-860.

33. Kohlstaedt, L.A.; Wang, J.; Friedman, J.M.; Rice, P.A.; Steitz, T.A. Crystal structure at 3.5 A resolution of HIV-1 reverse transcriptase complexed with an inhibitor. Science 1992, 256, 1783 1790.

34. Lapkouski, M.; Tian, L.; Miller, J.T.; Le Grice, S.F.; Yang, W. Complexes of HIV-1 RT, NNRTI and RNA/DNA hybrid reveal a structure compatible with RNA degradation. Nat. Struct. Mol. Biol. 2013, 20, 230-236.

35. Das, K.; Sarafianos, S.G.; Arnold, E. Structural requirements for RNA degradation by HIV-1 reverse transcriptase. Nat. Struct. Mol. Biol. 2013, 20, 1341-1342.

36. The PyMOL Molecular Graphics System, version 1.5.0.4. Schrödinger, LLC: New York, NY, USA, 2014..

37. Ren, J.; Bird, L.E.; Chamberlain, P.P.; Stewart-Jones, G.B.; Stuart, D.I.; Stammers, D.K. Structure of HIV-2 reverse transcriptase at 2.35-A resolution and the mechanism of resistance to nonnucleoside inhibitors. Proc. Natl. Acad. Sci. USA 2002, 99, 14410-14415.

38. Schuckmann, M.M.; Marchand, B.; Hachiya, A.; Kodama, E.N.; Kirby, K.A.; Singh, K.; Sarafianos, S.G. The N348I mutation at the connection subdomain of HIV-1 reverse transcriptase decreases binding to nevirapine. J. Biol. Chem. 2010, 285, 38700-38709.

39. Chung, S.; Miller, J.T.; Lapkouski, M.; Tian, L.; Yang, W.; Le Grice, S.F. Examining the role of the HIV-1 reverse transcriptase p51 subunit in positioning and hydrolysis of RNA/DNA hybrids. J. Biol. Chem. 2013, 288, 16177-16184.

40. Singh, K.; Marchand, B.; Kirby, K.A.; Michailidis, E.; Sarafianos, S.G. Structural aspects of drug resistance and inhibition of HIV-1 Reverse Transcriptase. Viruses 2010, 2, 606-638.

41. De Clercq, E. Antiviral drugs in current clinical use. J. Clin. Virol. 2004, 30, 115-133.

42. Parniak, M.A.; Sluis-Cremer, N. Inhibitors of HIV-1 reverse transcriptase. Adv. Pharmacol. 2000, 49, 67-109.

43. Sarafianos, S.G.; Marchand, B.; Das, K.; Himmel, D.M.; Parniak, M.A.; Hughes, S.H.; Arnold, E. Structure and function of HIV-1 reverse transcriptase: Molecular mechanisms of polymerization and inhibition. J. Mol. Biol. 2009, 385, 693-713.

44. Sarafianos, S.G.; Das, K.; Clark, A.D., Jr.; Ding, J.; Boyer, P.L.; Hughes, S.H.; Arnold, E. Lamivudine (3TC) resistance in HIV-1 reverse transcriptase involves steric hindrance with beta-branched amino acids. Proc. Natl. Acad. Sci. USA 1999, 96, 10027-10032.

45. Smerdon, S.J.; Jager, J.; Wang, J.; Kohlstaedt, L.A.; Chirino, A.J.; Friedman, J.M.; Rice, P.A.; Steitz, T.A. Structure of the binding site for nonnucleoside inhibitors of the reverse transcriptase of human immunodeficiency virus type 1. Proc. Natl. Acad. Sci. USA 1994, 91, 3911-3915. 
46. Tantillo, C.; Ding, J.; Jacobo-Molina, A.; Nanni, R.G.; Boyer, P.L.; Hughes, S.H.; Pauwels, R.; Andries, K.; Janssen, P.A.; Arnold, E. Locations of anti-AIDS drug binding sites and resistance mutations in the three-dimensional structure of HIV-1 reverse transcriptase. Implications for mechanisms of drug inhibition and resistance. J. Mol. Biol. 1994, 243, 369-387.

47. Johnson, V.A.; Calvez, V.; Gunthard, H.F.; Paredes, R.; Pillay, D.; Shafer, R.W.; Wensing, A.M.; Richman, D.D. Update of the drug resistance mutations in HIV-1: March 2013. Top. Antivir. Med. 2013, 21, 6-14.

48. Miller, M.D.; Margot, N.; Lu, B.; Zhong, L.; Chen, S.S.; Cheng, A.; Wulfsohn, M. Genotypic and phenotypic predictors of the magnitude of response to tenofovir disoproxil fumarate treatment in antiretroviral-experienced patients. J. Infect. Dis. 2004, 189, 837-846.

49. Whitcomb, J.M.; Parkin, N.T.; Chappey, C.; Hellmann, N.S.; Petropoulos, C.J. Broad nucleoside reverse-transcriptase inhibitor cross-resistance in human immunodeficiency virus type 1 clinical isolates. J. Infect. Dis. 2003, 188, 992-1000.

50. Kuritzkes, D.R.; Bassett, R.L.; Hazelwood, J.D.; Barrett, H.; Rhodes, R.A.; Young, R.K.; Johnson, V.A.; Adult, A.P.T. Rate of thymidine analogue resistance mutation accumulation with zidovudine- or stavudine-based regimens. J. Acquir. Immune Defic. Syndr. 2004, 36, 600-603.

51. ACD/ChemSketch Advanced Chemistry Development, I.: Toronto, ON, Canada. Available online: http://www.acdlabs.com/ (accessed on 7 July 2014).

52. Deval, J.; Selmi, B.; Boretto, J.; Egloff, M.P.; Guerreiro, C.; Sarfati, S.; Canard, B. The molecular mechanism of multidrug resistance by the Q151M human immunodeficiency virus type 1 reverse transcriptase and its suppression using alpha-boranophosphate nucleotide analogues. J. Biol. Chem. 2002, 277, 42097-42104.

53. Deval, J.; Navarro, J.M.; Selmi, B.; Courcambeck, J.; Boretto, J.; Halfon, P.; Garrido-Urbani, S.; Sire, J.; Canard, B. A loss of viral replicative capacity correlates with altered DNA polymerization kinetics by the human immunodeficiency virus reverse transcriptase bearing the K65R and L74V dideoxynucleoside resistance substitutions. J. Biol. Chem. 2004, 279, 25489-25496.

54. Deval, J.; White, K.L.; Miller, M.D.; Parkin, N.T.; Courcambeck, J.; Halfon, P.; Selmi, B.; Boretto, J.; Canard, B. Mechanistic basis for reduced viral and enzymatic fitness of HIV-1 reverse transcriptase containing both K65R and M184V mutations. J. Biol. Chem. 2004, 279, 509-516.

55. Sluis-Cremer, N.; Sheen, C.W.; Zelina, S.; Torres, P.S.; Parikh, U.M.; Mellors, J.W. Molecular mechanism by which the K70E mutation in human immunodeficiency virus type 1 reverse transcriptase confers resistance to nucleoside reverse transcriptase inhibitors. Antimicrob. Agents Chemother. 2007, 51, 48-53.

56. Das, K.; Arnold, E. HIV-1 reverse transcriptase and antiviral drug resistance. Part 2. Curr. Opin. Virol. 2013, 3, 119-128.

57. Krebs, R.; Immendorfer, U.; Thrall, S.H.; Wohrl, B.M.; Goody, R.S. Single-step kinetics of HIV-1 reverse transcriptase mutants responsible for virus resistance to nucleoside inhibitors zidovudine and 3-TC. Biochemistry 1997, 36, 10292-10300.

58. St Clair, M.H.; Martin, J.L.; Tudor-Williams, G.; Bach, M.C.; Vavro, C.L.; King, D.M.; Kellam, P.; Kemp, S.D.; Larder, B.A. Resistance to ddI and sensitivity to AZT induced by a mutation in HIV1 reverse transcriptase. Science 1991, 253, 1557-1559. 
59. Martin, J.L.; Wilson, J.E.; Haynes, R.L.; Furman, P.A. Mechanism of resistance of human immunodeficiency virus type 1 to 2',3'-dideoxyinosine. Proc. Natl. Acad. Sci. USA 1993, 90, 61356139 .

60. Matamoros, T.; Kim, B.; Menendez-Arias, L. Mechanistic insights into the role of Val75 of HIV-1 reverse transcriptase in misinsertion and mispair extension fidelity of DNA synthesis. J. Mol. Biol. 2008, 375, 1234-1248.

61. Ueno, T.; Mitsuya, H. Comparative enzymatic study of HIV-1 reverse transcriptase resistant to 2',3'-dideoxynucleotide analogs using the single-nucleotide incorporation assay. Biochemistry 1997, 36, 1092-1099.

62. Tisdale, M.; Kemp, S.D.; Parry, N.R.; Larder, B.A. Rapid in vitro selection of human immunodeficiency virus type 1 resistant to 3 '-thiacytidine inhibitors due to a mutation in the YMDD region of reverse transcriptase. Proc. Natl. Acad. Sci. USA 1993, 90, 5653-5656.

63. Selmi, B.; Boretto, J.; Sarfati, S.R.; Guerreiro, C.; Canard, B. Mechanism-based suppression of dideoxynucleotide resistance by K65R human immunodeficiency virus reverse transcriptase using an alpha-boranophosphate nucleoside analogue. J. Biol. Chem. 2001, 276, 48466-48472.

64. Feng, J.Y.; Myrick, F.T.; Margot, N.A.; Mulamba, G.B.; Rimsky, L.; Borroto-Esoda, K.; Selmi, B.; Canard, B. Virologic and enzymatic studies revealing the mechanism of K65R- and Q151M-associated HIV-1 drug resistance towards emtricitabine and lamivudine. Nucleosides Nucleotides Nucleic Acids 2006, 25, 89-107.

65. Shirasaka, T.; Kavlick, M.F.; Ueno, T.; Gao, W.Y.; Kojima, E.; Alcaide, M.L.; Chokekijchai, S.; Roy, B.M.; Arnold, E.; Yarchoan, R.; et al. Emergence of human immunodeficiency virus type 1 variants with resistance to multiple dideoxynucleosides in patients receiving therapy with dideoxynucleosides. Proc. Natl. Acad. Sci. USA 1995, 92, 2398-2402.

66. Tchesnokov, E.P.; Obikhod, A.; Massud, I.; Lisco, A.; Vanpouille, C.; Brichacek, B.; Balzarini, J.; McGuigan, C.; Derudas, M.; Margolis, L.; et al. Mechanisms associated with HIV-1 resistance to acyclovir by the V75I mutation in reverse transcriptase. J. Biol. Chem. 2009, 284, 21496-21504.

67. Frangeul, A.; Bussetta, C.; Deval, J.; Barral, K.; Alvarez, K.; Canard, B. Gln151 of HIV-1 reverse transcriptase acts as a steric gate towards clinically relevant acyclic phosphonate nucleotide analogues. Antivir. Ther. 2008, 13, 115-124.

68. Meyer, P.R.; Matsuura, S.E.; So, A.G.; Scott, W.A. Unblocking of chain-terminated primer by HIV-1 reverse transcriptase through a nucleotide-dependent mechanism. Proc. Natl. Acad. Sci. USA 1998, 95, 13471-13476.

69. Arion, D.; Kaushik, N.; McCormick, S.; Borkow, G.; Parniak, M.A. Phenotypic mechanism of HIV-1 resistance to 3'-azido-3'-deoxythymidine (AZT): Increased polymerization processivity and enhanced sensitivity to pyrophosphate of the mutant viral reverse transcriptase. Biochemistry 1998, 37, 15908-15917.

70. Sarafianos, S.G.; Clark, A.D., Jr.; Das, K.; Tuske, S.; Birktoft, J.J.; Ilankumaran, P.; Ramesha, A.R.; Sayer, J.M.; Jerina, D.M.; Boyer, P.L.; et al. Structures of HIV-1 reverse transcriptase with pre- and post-translocation AZTMP-terminated DNA. EMBO J. 2002, 21, 6614-6624.

71. Sarafianos, S.G.; Clark, A.D., Jr.; Tuske, S.; Squire, C.J.; Das, K.; Sheng, D.; Ilankumaran, P.; Ramesha, A.R.; Kroth, H.; Sayer, J.M.; et al. Trapping HIV-1 reverse transcriptase before and after translocation on DNA. J. Biol. Chem. 2003, 278, 16280-16288. 
72. Das, K.; Arnold, E. HIV-1 reverse transcriptase and antiviral drug resistance. Part 1. Curr. Opin. Virol. 2013, 3, 111-118.

73. Lacey, S.F.; Reardon, J.E.; Furfine, E.S.; Kunkel, T.A.; Bebenek, K.; Eckert, K.A.; Kemp, S.D.; Larder, B.A. Biochemical studies on the reverse transcriptase and RNase $\mathrm{H}$ activities from human immunodeficiency virus strains resistant to 3'-azido-3'-deoxythymidine. J. Biol. Chem. 1992, 267, 15789-15794.

74. Betancor, G.; Nevot, M.; Mendieta, J.; Gomez-Puertas, P.; Martinez, M.A.; Menendez-Arias, L. Molecular basis of the association of $\mathrm{H} 208 \mathrm{Y}$ and thymidine analogue resistance mutations M41L, L210W and T215Y in the HIV-1 reverse transcriptase of treated patients. Antivir. Res. 2014, 106, $42-52$.

75. Arion, D.; Parniak, M.A. HIV resistance to zidovudine: The role of pyrophosphorolysis. Drug Resist. Updat 1999, 2, 91-95.

76. Mas, A.; Parera, M.; Briones, C.; Soriano, V.; Martinez, M.A.; Domingo, E.; Menendez-Arias, L. Role of a dipeptide insertion between codons 69 and 70 of HIV-1 reverse transcriptase in the mechanism of AZT resistance. EMBO J. 2000, 19, 5752-5761.

77. Boyer, P.L.; Imamichi, T.; Sarafianos, S.G.; Arnold, E.; Hughes, S.H. Effects of the Delta67 complex of mutations in human immunodeficiency virus type 1 reverse transcriptase on nucleoside analog excision. J. Virol. 2004, 78, 9987-9997.

78. Meyer, P.R.; Matsuura, S.E.; Mian, A.M.; So, A.G.; Scott, W.A. A mechanism of AZT resistance: An increase in nucleotide-dependent primer unblocking by mutant HIV-1 reverse transcriptase. Mol. Cell 1999, 4, 35-43.

79. Meyer, P.R.; Matsuura, S.E.; Schinazi, R.F.; So, A.G.; Scott, W.A. Differential removal of thymidine nucleotide analogues from blocked DNA chains by human immunodeficiency virus reverse transcriptase in the presence of physiological concentrations of 2'-deoxynucleoside triphosphates. Antimicrob. Agents Chemother. 2000, 44, 3465-3472.

80. Lai, M.T.; Lu, M.; Felock, P.J.; Hrin, R.C.; Wang, Y.J.; Yan, Y.; Munshi, S.; McGaughey, G.B.; Tynebor, R.M.; Tucker, T.J.; et al. Distinct mutation pathways of non-subtype B HIV-1 during in vitro resistance selection with nonnucleoside reverse transcriptase inhibitors. Antimicrob. Agents Chemother. 2010, 54, 4812-4824.

81. Boyer, P.L.; Sarafianos, S.G.; Arnold, E.; Hughes, S.H. Selective excision of AZTMP by drug-resistant human immunodeficiency virus reverse transcriptase. J. Virol. 2001, 75, 4832-4842.

82. Arion, D.; Sluis-Cremer, N.; Parniak, M.A. Mechanism by which phosphonoformic acid resistance mutations restore 3'-azido-3'-deoxythymidine (AZT) sensitivity to AZT-resistant HIV-1 reverse transcriptase. J. Biol. Chem. 2000, 275, 9251-9255.

83. Sarafianos, S.G.; Hughes, S.H.; Arnold, E. Designing anti-AIDS drugs targeting the major mechanism of HIV-1 RT resistance to nucleoside analog drugs. Int. J. Biochem. Cell Biol. 2004, $36,1706-1715$.

84. Novitsky, V.; Wester, C.W.; DeGruttola, V.; Bussmann, H.; Gaseitsiwe, S.; Thomas, A.; Moyo, S.; Musonda, R.; van Widenfelt, E.; Marlink, R.G.; et al. The reverse transcriptase $67 \mathrm{~N} 70 \mathrm{R} 215 \mathrm{Y}$ genotype is the predominant TAM pathway associated with virologic failure among HIV type 1Cinfected adults treated with ZDV/ddI-containing HAART in southern Africa. AIDS Res. Hum. Retroviruses 2007, 23, 868-878. 
85. Deshpande, A.; Jauvin, V.; Magnin, N.; Pinson, P.; Faure, M.; Masquelier, B.; Aurillac-Lavignolle, V.; Fleury, H.J. Resistance mutations in subtype C HIV type 1 isolates from Indian patients of Mumbai receiving NRTIs plus NNRTIs and experiencing a treatment failure: Resistance to AR. AIDS Res. Hum. Retroviruses 2007, 23, 335-340.

86. Hosseinipour, M.C.; van Oosterhout, J.J.; Weigel, R.; Phiri, S.; Kamwendo, D.; Parkin, N.; Fiscus, S.A.; Nelson, J.A.; Eron, J.J.; Kumwenda, J. The public health approach to identify antiretroviral therapy failure: High-level nucleoside reverse transcriptase inhibitor resistance among Malawians failing first-line antiretroviral therapy. AIDS 2009, 23, 1127-1134.

87. Barth, R.E.; Wensing, A.M.; Tempelman, H.A.; Moraba, R.; Schuurman, R.; Hoepelman, A.I. Rapid accumulation of nonnucleoside reverse transcriptase inhibitor-associated resistance: Evidence of transmitted resistance in rural South Africa. AIDS 2008, 22, 2210-2212.

88. Doualla-Bell, F.; Avalos, A.; Brenner, B.; Gaolathe, T.; Mine, M.; Gaseitsiwe, S.; Oliveira, M.; Moisi, D.; Ndwapi, N.; Moffat, H.; et al. High prevalence of the K65R mutation in human immunodeficiency virus type 1 subtype $\mathrm{C}$ isolates from infected patients in Botswana treated with didanosine-based regimens. Antimicrob. Agents Chemother. 2006, 50, 4182-4185.

89. Sunpath, H.; Wu, B.; Gordon, M.; Hampton, J.; Johnson, B.; Moosa, M.Y.; Ordonez, C.; Kuritzkes, D.R.; Marconi, V.C. High rate of $\mathrm{K} 65 \mathrm{R}$ for antiretroviral therapy-naive patients with subtype C HIV infection failing a tenofovir-containing first-line regimen. AIDS 2012, 26, 1679-1684.

90. Brenner, B.G.; Coutsinos, D. The K65R mutation in HIV-1 reverse transcriptase: Genetic barriers, resistance profile and clinical implications. HIV Ther. 2009, 3, 583-594.

91. Orrell, C.; Walensky, R.P.; Losina, E.; Pitt, J.; Freedberg, K.A.; Wood, R. HIV type-1 clade C resistance genotypes in treatment-naive patients and after first virological failure in a large community antiretroviral therapy programme. Antivir. Ther. 2009, 14, 523-531.

92. Turner, D.; Shahar, E.; Katchman, E.; Kedem, E.; Matus, N.; Katzir, M.; Hassoun, G.; Pollack, S.; Kessner, R.; Wainberg, M.A.; et al. Prevalence of the K65R resistance reverse transcriptase mutation in different HIV-1 subtypes in Israel. J. Med. Virol. 2009, 81, 1509-1512.

93. Deshpande, A.; Jeannot, A.C.; Schrive, M.H.; Wittkop, L.; Pinson, P.; Fleury, H.J. Analysis of RT sequences of subtype C HIV-type 1 isolates from indian patients at failure of a first-line treatment according to clinical and/or immunological WHO guidelines. AIDS Res. Hum. Retroviruses 2010, 26, 343-350.

94. Gupta, R.K.; Chrystie, I.L.; O’Shea, S.; Mullen, J.E.; Kulasegaram, R.; Tong, C.Y. K65R and Y181C are less prevalent in HAART-experienced HIV-1 subtype A patients. AIDS 2005, 19, 1916-1919.

95. Fontella, R.; Soares, M.A.; Schrago, C.G. On the origin of HIV-1 subtype C in South America. AIDS 2008, 22, 2001-2011.

96. Coutsinos, D.; Invernizzi, C.F.; Moisi, D.; Oliveira, M.; Martinez-Cajas, J.L.; Brenner, B.G.; Wainberg, M.A. A template-dependent dislocation mechanism potentiates K65R reverse transcriptase mutation development in subtype C variants of HIV-1. PLoS One 2011, 6, e20208. 
97. Coutsinos, D.; Invernizzi, C.F.; Xu, H.; Moisi, D.; Oliveira, M.; Brenner, B.G.; Wainberg, M.A. Template usage is responsible for the preferential acquisition of the K65R reverse transcriptase mutation in subtype $\mathrm{C}$ variants of human immunodeficiency virus type 1. J. Virol. 2009, 83, 20292033.

98. Antinori, A.; Zaccarelli, M.; Cingolani, A.; Forbici, F.; Rizzo, M.G.; Trotta, M.P.; di Giambenedetto, S.; Narciso, P.; Ammassari, A.; Girardi, E.; et al. Cross-resistance among nonnucleoside reverse transcriptase inhibitors limits recycling efavirenz after nevirapine failure. AIDS Res. Hum. Retroviruses 2002, 18, 835-838.

99. Brenner, B.; Turner, D.; Oliveira, M.; Moisi, D.; Detorio, M.; Carobene, M.; Marlink, R.G.; Schapiro, J.; Roger, M.; Wainberg, M.A. A V106M mutation in HIV-1 clade C viruses exposed to efavirenz confers cross-resistance to non-nucleoside reverse transcriptase inhibitors. AIDS 2003, 17, F1-F5.

100. Lazzarin, A.; Campbell, T.; Clotet, B.; Johnson, M.; Katlama, C.; Moll, A.; Towner, W.; Trottier, B.; Peeters, M.; Vingerhoets, J.; et al. Efficacy and safety of TMC125 (etravirine) in treatment-experienced HIV-1-infected patients in DUET-2: 24-week results from a randomised, double-blind, placebo-controlled trial. Lancet 2007, 370, 39-48.

101. Madruga, J.V.; Cahn, P.; Grinsztejn, B.; Haubrich, R.; Lalezari, J.; Mills, A.; Pialoux, G.; Wilkin, T.; Peeters, M.; Vingerhoets, J.; et al. Efficacy and safety of TMC125 (etravirine) in treatmentexperienced HIV-1-infected patients in DUET-1: 24-week results from a randomised, doubleblind, placebo-controlled trial. Lancet 2007, 370, 29-38.

102. Janssen, P.A.; Lewi, P.J.; Arnold, E.; Daeyaert, F.; de Jonge, M.; Heeres, J.; Koymans, L.; Vinkers, M.; Guillemont, J.; Pasquier, E.; et al. In search of a novel anti-HIV drug: Multidisciplinary coordination in the discovery of 4-[[4-[[4-[(1E)-2-cyanoethenyl]-2,6-dimethylphenyl]amino]-2pyrimidinyl]amino]benzonitrile (R278474, rilpivirine). J. Med. Chem. 2005, 48, 1901-1909.

103. Michailidis, E.; Singh, K.; Ryan, E.M.; Hachiya, A.; Ong, Y.T.; Kirby, K.A.; Marchand, B.; Kodama, E.N.; Mitsuya, H.; Parniak, M.A.; et al. Effect of translocation defective reverse transcriptase inhibitors on the activity of N348I, a connection subdomain drug resistant HIV-1 reverse transcriptase mutant. Cell Mol. Biol. (Noisy-le-grand) 2012, 58, 187-195.

104. Kulkarni, R.; Babaoglu, K.; Lansdon, E.B.; Rimsky, L.; Van Eygen, V.; Picchio, G.; Svarovskaia, E.; Miller, M.D.; White, K.L. The HIV-1 reverse transcriptase M184I mutation enhances the E138K-associated resistance to rilpivirine and decreases viral fitness. J. Acquir. Immune Defic. Syndr. 2012, 59, 47-54.

105. Spence, R.A.; Kati, W.M.; Anderson, K.S.; Johnson, K.A. Mechanism of inhibition of HIV-1 reverse transcriptase by nonnucleoside inhibitors. Science 1995, 267, 988-993.

106. Spence, R.A.; Anderson, K.S.; Johnson, K.A. HIV-1 reverse transcriptase resistance to nonnucleoside inhibitors. Biochemistry 1996, 35, 1054-1063.

107. Maga, G.; Amacker, M.; Ruel, N.; Hubscher, U.; Spadari, S. Resistance to nevirapine of HIV-1 reverse transcriptase mutants: Loss of stabilizing interactions and thermodynamic or steric barriers are induced by different single amino acid substitutions. J. Mol. Biol. 1997, 274, $738-747$. 
108. Ren, J.; Nichols, C.; Bird, L.; Chamberlain, P.; Weaver, K.; Short, S.; Stuart, D.I.; Stammers, D.K. Structural mechanisms of drug resistance for mutations at codons 181 and 188 in HIV-1 reverse transcriptase and the improved resilience of second generation non-nucleoside inhibitors. J. Mol. Biol. 2001, 312, 795-805.

109. Ren, J.; Stammers, D.K. Structural basis for drug resistance mechanisms for non-nucleoside inhibitors of HIV reverse transcriptase. Virus Res. 2008, 134, 157-170.

110. Brenner, B.G.; Oliveira, M.; Doualla-Bell, F.; Moisi, D.D.; Ntemgwa, M.; Frankel, F.; Essex, M.; Wainberg, M.A. HIV-1 subtype C viruses rapidly develop K65R resistance to tenofovir in cell culture. AIDS 2006, 20, F9-F13.

111. Arrive, E.; Newell, M.L.; Ekouevi, D.K.; Chaix, M.L.; Thiebaut, R.; Masquelier, B.; Leroy, V.; Perre, P.V.; Rouzioux, C.; Dabis, F.; et al. Prevalence of resistance to nevirapine in mothers and children after single-dose exposure to prevent vertical transmission of HIV-1: A meta-analysis. Int. J. Epidemiol. 2007, 36, 1009-1021.

112. Eshleman, S.H.; Guay, L.A.; Wang, J.; Mwatha, A.; Brown, E.R.; Musoke, P.; Mmiro, F.; Jackson, J.B. Distinct patterns of emergence and fading of K103N and Y181C in women with subtype A vs. D after single-dose nevirapine: HIVNET 012. J. Acquir. Immune Defic. Syndr. 2005, 40, 24 29.

113. Eshleman, S.H.; Mracna, M.; Guay, L.A.; Deseyve, M.; Cunningham, S.; Mirochnick, M.; Musoke, P.; Fleming, T.; Glenn Fowler, M.; Mofenson, L.M.; et al. Selection and fading of resistance mutations in women and infants receiving nevirapine to prevent HIV-1 vertical transmission (HIVNET 012). AIDS 2001, 15, 1951-1957.

114. Loemba, H.; Brenner, B.; Parniak, M.A.; Ma'ayan, S.; Spira, B.; Moisi, D.; Oliveira, M.; Detorio, M.; Wainberg, M.A. Genetic divergence of human immunodeficiency virus type 1 Ethiopian clade C reverse transcriptase (RT) and rapid development of resistance against nonnucleoside inhibitors of RT. Antimicrob. Agents Chemother. 2002, 46, 2087-2094.

115. Marconi, V.C.; Sunpath, H.; Lu, Z.; Gordon, M.; Koranteng-Apeagyei, K.; Hampton, J.; Carpenter, S.; Giddy, J.; Ross, D.; Holst, H.; et al. Prevalence of HIV-1 drug resistance after failure of a first highly active antiretroviral therapy regimen in KwaZulu Natal, South Africa. Clin. Infect. Dis. 2008, 46, 1589-1597.

116. Ly, N.; Recordon-Pinson, P.; Phoung, V.; Srey, C.; Kruy, L.S.; Koum, K.; Chhum, V.; Glaziou, P.; Fleury, H.J.; Reynes, J.M. Characterization of mutations in HIV type 1 isolates from 144 Cambodian recently infected patients and pregnant women naive to antiretroviral drugs. AIDS Res. Hum. Retroviruses 2005, 21, 971-976.

117. Rajesh, L.; Karunaianantham, R.; Narayanan, P.R.; Swaminathan, S. Antiretroviral drug-resistant mutations at baseline and at time of failure of antiretroviral therapy in HIV type 1-coinfected TB patients. AIDS Res. Hum. Retroviruses 2009, 25, 1179-1185.

118. Grossman, Z.; Istomin, V.; Averbuch, D.; Lorber, M.; Risenberg, K.; Levi, I.; Chowers, M.; Burke, M.; Bar Yaacov, N.; Schapiro, J.M. Genetic variation at NNRTI resistance-associated positions in patients infected with HIV-1 subtype C. AIDS 2004, 18, 909-915. 
119. Cohen, C.J.; Andrade-Villanueva, J.; Clotet, B.; Fourie, J.; Johnson, M.A.; Ruxrungtham, K.; Wu, H.; Zorrilla, C.; Crauwels, H.; Rimsky, L.T.; et al. Rilpivirine versus efavirenz with two background nucleoside or nucleotide reverse transcriptase inhibitors in treatment-naive adults infected with HIV-1 (THRIVE): A phase 3, randomised, non-inferiority trial. Lancet 2011, 378, $229-237$.

120. Hu, Z.; Kuritzkes, D.R. Interaction of reverse transcriptase (RT) mutations conferring resistance to lamivudine and etravirine: Effects on fitness and RT activity of human immunodeficiency virus type 1. J. Virol. 2011, 85, 11309-11314.

121. Xu, H.T.; Asahchop, E.L.; Oliveira, M.; Quashie, P.K.; Quan, Y.; Brenner, B.G.; Wainberg, M.A. Compensation by the E138K mutation in HIV-1 reverse transcriptase for deficits in viral replication capacity and enzyme processivity associated with the M184I/V mutations. J. Virol. 2011, 85, 11300-11308.

122. Maiga, A.I.; Descamps, D.; Morand-Joubert, L.; Malet, I.; Derache, A.; Cisse, M.; Koita, V.; Akonde, A.; Diarra, B.; Wirden, M.; et al. Resistance-associated mutations to etravirine (TMC-125) in antiretroviral-naive patients infected with non-B HIV-1 subtypes. Antimicrob. Agents Chemother. 2010, 54, 728-733.

123. Asahchop, E.L.; Oliveira, M.; Wainberg, M.A.; Brenner, B.G.; Moisi, D.; Toni, T.; Tremblay, C.L. Characterization of the E138K resistance mutation in HIV-1 reverse transcriptase conferring susceptibility to etravirine in B and non-B HIV-1 subtypes. Antimicrob. Agents Chemother. 2011, $55,600-607$.

124. Neogi, U.; Shet, A.; Shamsundar, R.; Ekstrand, M.L. Selection of nonnucleoside reverse transcriptase inhibitor-associated mutations in HIV-1 subtype C: Evidence of etravirine cross-resistance. AIDS 2011, 25, 1123-1126.

125. Lambert-Niclot, S.; Charpentier, C.; Storto, A.; Fofana, D.; Soulie, C.; Fourati, S.; Wirden, M.; Morand-Joubert, L.; Masquelier, B.; Flandre, P.; et al. Rilpivirine, emtricitabine and tenofovir resistance in HIV-1-infected rilpivirine-naive patients failing antiretroviral therapy. J. Antimicrob. Chemother. 2014, 69, 1086-1089.

126. Christen, M.T.; Menon, L.; Myshakina, N.S.; Ahn, J.; Parniak, M.A.; Ishima, R. Structural basis of the allosteric inhibitor interaction on the HIV-1 reverse transcriptase RNase $\mathrm{H}$ domain. Chem. Biol. Drug Des. 2012, 80, 706-716. PMCID: PMC3465473.

127. European Medicines Agency. Edurant ${ }^{\circledR} 25 \mathrm{mg}$ Film-coated Tablets: Summary of Product Characteristics. Available online: http://www.ema.europa.eu/docs/en_GB/document_library/ EPAR_-_Product_Information/human/002264/WC500118874.pdf (accessed on 5 May 2014).

128. Wensing, A.M.; van de Vijver, D.A.; Angarano, G.; Asjo, B.; Balotta, C.; Boeri, E.; Camacho, R.; Chaix, M.L.; Costagliola, D.; De Luca, A.; et al. Prevalence of drug-resistant HIV-1 variants in untreated individuals in Europe: Implications for clinical management. J. Infect. Dis. 2005, 192, 958-966.

129. Sluis-Cremer, N.; Jordan, M.R.; Huber, K.; Wallis, C.L.; Bertagnolio, S.; Mellors, J.W.; Parkin, N.T.; Harrigan, P.R. E138A in HIV-1 reverse transcriptase is more common in subtype C than B: Implications for rilpivirine use in resource-limited settings. Antivir. Res. 2014, 107, 31-34. 
130. Bunupuradah, T.; Ananworanich, J.; Chetchotisakd, P.; Kantipong, P.; Jirajariyavej, S.; Sirivichayakul, S.; Munsakul, W.; Prasithsirikul, W.; Sungkanuparph, S.; Bowonwattanuwong, C.; et al. Etravirine and rilpivirine resistance in HIV-1 subtype CRF01_AE-infected adults failing nonnucleoside reverse transcriptase inhibitor-based regimens. Antivir. Ther. 2011, 16, 1113-1121.

131. Kantor, R.; Katzenstein, D.A.; Efron, B.; Carvalho, A.P.; Wynhoven, B.; Cane, P.; Clarke, J.; Sirivichayakul, S.; Soares, M.A.; Snoeck, J.; et al. Impact of HIV-1 subtype and antiretroviral therapy on protease and reverse transcriptase genotype: Results of a global collaboration. PLoS Med 2005, 2, e112.

132. Santoro, M.M.; Perno, C.F. HIV-1 Genetic Variability and Clinical Implications. ISRN Microbiol 2013, 2013, 481314.

133. Santoro, M.M.; Alteri, C.; Ronga, L.; Flandre, P.; Fabeni, L.; Mercurio, F.; D'Arrigo, R.; Gori, C.; Palamara, G.; Bertoli, A.; et al. Comparative analysis of drug resistance among $\mathrm{B}$ and the most prevalent non-B HIV type 1 subtypes (C, F, and CRF02_AG) in Italy. AIDS Res. Hum. Retroviruses 2012, 28, 1285-1293.

134. Flys, T.S.; Chen, S.; Jones, D.C.; Hoover, D.R.; Church, J.D.; Fiscus, S.A.; Mwatha, A.; Guay, L.A.; Mmiro, F.; Musoke, P.; et al. Quantitative analysis of HIV-1 variants with the K103N resistance mutation after single-dose nevirapine in women with HIV-1 subtypes A, C, and D. J. Acquir. Immune Defic. Syndr. 2006, 42, 610-613.

135. Johnson, J.A.; Li, J.F.; Morris, L.; Martinson, N.; Gray, G.; McIntyre, J.; Heneine, W. Emergence of drug-resistant HIV-1 after intrapartum administration of single-dose nevirapine is substantially underestimated. J. Infect. Dis. 2005, 192, 16-23.

136. Shafer, R.W. Rationale and uses of a public HIV drug-resistance database. J. Infect. Dis. 2006, 194, S51-S58.

137. McCormick, A.L.; Parry, C.M.; Crombe, A.; Goodall, R.L.; Gupta, R.K.; Kaleebu, P.; Kityo, C.; Chirara, M.; Towers, G.J.; Pillay, D. Impact of the N348I mutation in HIV-1 reverse transcriptase on nonnucleoside reverse transcriptase inhibitor resistance in non-subtype B HIV-1. Antimicrob. Agents Chemother. 2011, 55, 1806-1809.

138. Brehm, J.H.; Koontz, D.L.; Wallis, C.L.; Shutt, K.A.; Sanne, I.; Wood, R.; McIntyre, J.A.; Stevens, W.S.; Sluis-Cremer, N.; Mellors, J.W.; et al. Frequent emergence of N348I in HIV-1 subtype C reverse transcriptase with failure of initial therapy reduces susceptibility to reverse-transcriptase inhibitors. Clin. Infect. Dis. 2012, 55, 737-745.

139. Nikolenko, G.N.; Delviks-Frankenberry, K.A.; Palmer, S.; Maldarelli, F.; Fivash, M.J., Jr.; Coffin, J.M.; Pathak, V.K. Mutations in the connection domain of HIV-1 reverse transcriptase increase 3'azido-3'-deoxythymidine resistance. Proc. Natl. Acad. Sci. USA 2007, 104, 317-322.

140. Vijayan, R.S.; Arnold, E.; Das, K. Molecular dynamics study of HIV-1 RT-DNA-nevirapine complexes explains NNRTI inhibition and resistance by connection mutations. Proteins 2014, 82, 815-829.

141. Delviks-Frankenberry, K.A.; Lengruber, R.B.; Santos, A.F.; Silveira, J.M.; Soares, M.A.; Kearney, M.F.; Maldarelli, F.; Pathak, V.K. Connection subdomain mutations in HIV-1 subtype-C treatmentexperienced patients enhance NRTI and NNRTI drug resistance. Virology 2013, 435, 433-441. 
142. Cane, P.; Chrystie, I.; Dunn, D.; Evans, B.; Geretti, A.M.; Green, H.; Phillips, A.; Pillay, D.; Porter, K.; Pozniak, A.; et al. Time trends in primary resistance to HIV drugs in the United Kingdom: Multicentre observational study. BMJ 2005, 331, 1368.

143. Shet, A.; Berry, L.; Mohri, H.; Mehandru, S.; Chung, C.; Kim, A.; Jean-Pierre, P.; Hogan, C.; Simon, V.; Boden, D.; et al. Tracking the prevalence of transmitted antiretroviral drug-resistant HIV-1: A decade of experience. J. Acquir. Immune Defic. Syndr. 2006, 41, 439-446.

144. Smith, D.; Moini, N.; Pesano, R.; Cachay, E.; Aiem, H.; Lie, Y.; Richman, D.; Little, S. Clinical utility of HIV standard genotyping among antiretroviral-naive individuals with unknown duration of infection. Clin. Infect. Dis. 2007, 44, 456-458.

145. Bennett, D.E.; Camacho, R.J.; Otelea, D.; Kuritzkes, D.R.; Fleury, H.; Kiuchi, M.; Heneine, W.; Kantor, R.; Jordan, M.R.; Schapiro, J.M.; et al. Drug resistance mutations for surveillance of transmitted HIV-1 drug-resistance: 2009 update. PLoS One 2009, 4, e4724.

146. Shafer, R.W.; Rhee, S.Y.; Bennett, D.E. Consensus drug resistance mutations for epidemiological surveillance: Basic principles and potential controversies. Antivir. Ther. 2008, 13, 59-68.

147. Kantor, R.; Katzenstein, D. Polymorphism in HIV-1 non-subtype B protease and reverse transcriptase and its potential impact on drug susceptibility and drug resistance evolution. AIDS Rev. 2003, 5, 25-35.

148. Martinez-Cajas, J.L.; Pant-Pai, N.; Klein, M.B.; Wainberg, M.A. Role of genetic diversity amongst HIV-1 non-B subtypes in drug resistance: A systematic review of virologic and biochemical evidence. AIDS Rev. 2008, 10, 212-223.

149. Hirsch, M.S.; Brun-Vezinet, F.; Clotet, B.; Conway, B.; Kuritzkes, D.R.; D’Aquila, R.T.; Demeter, L.M.; Hammer, S.M.; Johnson, V.A.; Loveday, C.; et al. Antiretroviral drug resistance testing in adults infected with human immunodeficiency virus type 1: 2003 recommendations of an International AIDS Society-USA Panel. Clin. Infect. Dis. 2003, 37, 113-128.

150. Descamps, D.; Collin, G.; Letourneur, F.; Apetrei, C.; Damond, F.; Loussert-Ajaka, I.; Simon, F.; Saragosti, S.; Brun-Vezinet, F. Susceptibility of human immunodeficiency virus type 1 group O isolates to antiretroviral agents: In vitro phenotypic and genotypic analyses. J. Virol. 1997, 71, 8893-8898.

151. Tuaillon, E.; Gueudin, M.; Lemee, V.; Gueit, I.; Roques, P.; Corrigan, G.E.; Plantier, J.C.; Simon, F.; Braun, J. Phenotypic susceptibility to nonnucleoside inhibitors of virion-associated reverse transcriptase from different HIV types and groups. J. Acquir. Immune Defic. Syndr. 2004, 37, 1543-1549.

152. Menendez-Arias, L.; Betancor, G.; Matamoros, T. HIV-1 reverse transcriptase connection subdomain mutations involved in resistance to approved non-nucleoside inhibitors. Antivir. Res. 2011, 92, 139-149.

153. Santos, A.F.; Silveira, J.; Muniz, C.P.; Tornatore, M.; Goes, L.R.; Mendoza-Sassi, R.A.; Martinez, A.M.; Tupinambas, U.; Greco, D.B.; Soares, M.A. Primary HIV-1 drug resistance in the Cterminal domains of viral reverse transcriptase among drug-naive patients from Southern Brazil. J. Clin. Virol. 2011, 52, 373-376. 
154. Tanuma, J.; Hachiya, A.; Ishigaki, K.; Gatanaga, H.; Lien, T.T.; Hien, N.D.; Kinh, N.V.; Kaku, M.; Oka, S. Impact of CRF01_AE-specific polymorphic mutations G335D and A371V in the connection subdomain of human immunodeficiency virus type 1 (HIV-1) reverse transcriptase (RT) on susceptibility to nucleoside RT inhibitors. Microbes. Infect. 2010, 12, 1170-1177.

155. Muniz, C.P.; Soares, M.A.; Santos, A.F. Early selection of resistance-associated mutations in HIV1 RT C-terminal domains across different subtypes: Role of the genetic barrier to resistance. $J$. Antimicrob. Chemother. 2014, 69, 2741-2745.

156. Hoffmann, C.J.; Charalambous, S.; Sim, J.; Ledwaba, J.; Schwikkard, G.; Chaisson, R.E.; Fielding, K.L.; Churchyard, G.J.; Morris, L.; Grant, A.D. Viremia, resuppression, and time to resistance in human immunodeficiency virus (HIV) subtype C during first-line antiretroviral therapy in South Africa. Clin. Infect. Dis. 2009, 49, 1928-1935.

157. El-Khatib, Z.; Ekstrom, A.M.; Ledwaba, J.; Mohapi, L.; Laher, F.; Karstaedt, A.; Charalambous, S.; Petzold, M.; Katzenstein, D.; Morris, L. Viremia and drug resistance among HIV-1 patients on antiretroviral treatment: A cross-sectional study in Soweto, South Africa. AIDS 2010, 24, 1679-1687.

158. Neogi, U.; Heylen, E.; Shet, A.; Chandy, S.; Shamsunder, R.; Sonnerborg, A.; Ekstrand, M.L. Long-term efficacy of first line antiretroviral therapy in Indian HIV-1 infected patients: A longitudinal cohort study. PLoS One 2013, 8, e55421.

159. Cihlar, T.; Ray, A.S. Nucleoside and nucleotide HIV reverse transcriptase inhibitors: 25 years after zidovudine. Antivir. Res. 2010, 85, 39-58.

160. Waters, L.J.; Moyle, G.; Bonora, S.; D'Avolio, A.; Else, L.; Mandalia, S.; Pozniak, A.; Nelson, M.; Gazzard, B.; Back, D.; et al. Abacavir plasma pharmacokinetics in the absence and presence of atazanavir/ritonavir or lopinavir/ritonavir and vice versa in HIV-infected patients. Antivir. Ther. 2007, 12, 825-830.

161. Cahn, P.; Wainberg, M.A. Resistance profile of the new nucleoside reverse transcriptase inhibitor apricitabine. J. Antimicrob. Chemother. 2010, 65, 213-217.

162. Murphey-Corb, M.; Rajakumar, P.; Michael, H.; Nyaundi, J.; Didier, P.J.; Reeve, A.B.; Mitsuya, H.; Sarafianos, S.G.; Parniak, M.A. Response of simian immunodeficiency virus to the novel nucleoside reverse transcriptase inhibitor 4'-ethynyl-2-fluoro-2'-deoxyadenosine in vitro and in vivo. Antimicrob. Agents Chemother. 2012, 56, 4707-4712.

163. Michailidis, E.; Marchand, B.; Kodama, E.N.; Singh, K.; Matsuoka, M.; Kirby, K.A.; Ryan, E.M.; Sawani, A.M.; Nagy, E.; Ashida, N.; et al. Mechanism of inhibition of HIV-1 reverse transcriptase by 4'-Ethynyl-2-fluoro-2'-deoxyadenosine triphosphate, a translocation-defective reverse transcriptase inhibitor. J. Biol. Chem. 2009, 284, 35681-35691.

164. Muftuoglu, Y.; Sohl, C.D.; Mislak, A.C.; Mitsuya, H.; Sarafianos, S.G.; Anderson, K.S. Probing the molecular mechanism of action of the HIV-1 reverse transcriptase inhibitor 4'-ethynyl-2fluoro-2'-deoxyadenosine (EFdA) using pre-steady-state kinetics. Antivir. Res. 2014, 106, 1-4.

165. Michailidis, E.; Huber, A.D.; Ryan, E.M.; Ong, Y.T.; Leslie, M.D.; Matzek, K.B.; Singh, K.; Marchand, B.; Hagedorn, A.N.; Kirby, K.A.; et al. 4'-Ethynyl-2-fluoro-2'-deoxyadenosine (EFdA) Inhibits HIV-1 Reverse Transcriptase with Multiple Mechanisms. J. Biol. Chem. 2014, 289, 24533-24548. 
166. Kawamoto, A.; Kodama, E.; Sarafianos, S.G.; Sakagami, Y.; Kohgo, S.; Kitano, K.; Ashida, N.; Iwai, Y.; Hayakawa, H.; Nakata, H.; et al. 2'-deoxy-4'-C-ethynyl-2-halo-adenosines active against drug-resistant human immunodeficiency virus type 1 variants. Int. J. Biochem. Cell Biol. 2008, 40, 2410-2420.

167. Sohl, C.D.; Singh, K.; Kasiviswanathan, R.; Copeland, W.C.; Mitsuya, H.; Sarafianos, S.G.; Anderson, K.S. Mechanism of interaction of human mitochondrial DNA polymerase gamma with the novel nucleoside reverse transcriptase inhibitor 4'-ethynyl-2-fluoro-2'-deoxyadenosine indicates a low potential for host toxicity. Antimicrob. Agents Chemother. 2012, 56, 1630-1634.

168. Michailidis, E.; Ryan, E.M.; Hachiya, A.; Kirby, K.A.; Marchand, B.; Leslie, M.D.; Huber, A.D.; Ong, Y.T.; Jackson, J.C.; Singh, K.; et al. Hypersusceptibility mechanism of Tenofovir-resistant HIV to EFdA. Retrovirology 2013, 10, 65.

(C) 2014 by the authors; licensee MDPI, Basel, Switzerland. This article is an open access article distributed under the terms and conditions of the Creative Commons Attribution license (http://creativecommons.org/licenses/by/3.0/). 